\title{
PREDATION STRUCTURES COMMUNITIES AT DEEP-SEA HYDROTHERMAL VENTS
}

\author{
Fiorenza Micheli, ${ }^{1,6}$ Charles H. Peterson,${ }^{2}$ Lauren S. Mullineaux, ${ }^{3}$ Charles R. Fisher,${ }^{4}$ \\ Susan W. Mills, ${ }^{3}$ Gorka Sancho, ${ }^{3}$ Galen A. Johnson, ${ }^{2}$ And Hunter S. Lenihan ${ }^{5}$ \\ ${ }^{1}$ Hopkins Marine Station, Stanford University, Pacific Grove, California 93950 USA \\ ${ }_{2}^{2}$ Institute of Marine Sciences, University of North Carolina at Chapel Hill, Morehead City, North Carolina 28557 USA \\ ${ }^{3}$ Biology Department, Woods Hole Oceanographic Institution, Woods Hole, Massachusetts 02543 USA \\ ${ }^{4}$ Biology Department, Pennsylvania State University, University Park, Pennsylvania 16802 USA \\ ${ }^{5}$ Marine Science Institute, University of California, Santa Barbara, California 93106 USA
}

\begin{abstract}
The structure and dynamics of natural communities result from the interplay of abiotic and biotic factors. We used manipulative field experiments to determine the relative roles of abiotic conditions and biotic interactions in structuring deep-sea $(2500 \mathrm{~m}$ depth) communities along environmental gradients around hydrothermal vents of the eastern tropical Pacific Ocean (East Pacific Rise, at $9^{\circ} 50^{\prime} \mathrm{N}$ ). We tested (1) whether predation by crabs and fishes affects the recruitment of benthic species and subsequent community structure and (2) whether the effects of predation vary along the steep gradients of temperature, oxygen, sulfide, and metal concentrations near vents. Recruitment substrates (basalt cubic blocks, roughly $10 \mathrm{~cm}$ on a side), both uncaged and caged to exclude predators (crabs, fishes, whelks, and octopi), were deployed along a decreasing vent fluid-flux gradient. The exclusion of predators for 8 mo increased the abundance of small mobile gastropods and amphipod crustaceans but decreased the abundance of sessile invertebrates, including juvenile vestimentiferan worms, tubiculous polychaetes, and mussels. Effects of predation were strongest nearest to hydrothermal vents, where abiotic environmental conditions were most extreme but productivity and the overall abundances of benthic invertebrates and mobile predators were the greatest. Additional 5-mo experiments conducted at three different locations showed similar trends at all sites, indicating that these effects of predation on benthic community structure are repeatable. Stomach-content analyses of the most abundant predators found at vents indicated that the zoarcid fish (Thermarces cerberus) primarily feeds on the vent snail Cyathermia naticoides, the limpet Lepetodrilus elevatus, and the amphipod crustacean Ventiella sulfuris, the very species that showed the greatest increase following predator exclusion. In contrast, brachyuran (Bythograea thermydron) and galatheid (Munidopsis subsquamosa) crab stomachs did not contain small mobile grazers, and crabs presented with arrays of the most common vent invertebrate species preferred mussels and vestimentiferans over limpets. Our results indicate that predation by large mobile predators influences the structure of hydrothermal vent communities, directly by reducing the abundance of gastropod prey species, and indirectly by reducing gastropod grazing and by bulldozing of recruits of sessile invertebrates.
\end{abstract}

Key words: $\quad$ biotic interactions; community structure; deep sea; environmental gradients; hydrothermal vents; indirect effects; marine invertebrates; predation; recruitment.

\section{INTRODUCTION}

The discovery of deep-sea hydrothermal vents and associated animal communities in 1977 was one of the most exciting oceanographic discoveries of the 20th century and has challenged our way of thinking about biological systems. A great deal of effort has been directed to elucidating the physiological adaptations that allow hydrothermal vent organisms to withstand the extreme and highly variable environmental conditions present at vents, including the absence of sunlight, high and variable temperatures $\left(1.5^{\circ}-60^{\circ} \mathrm{C}\right)$, high pressure $\left(2 \times 10^{4}-3 \times 10^{4} \mathrm{kPa}\right)$, low and variable $\mathrm{pH}(2.8-$ 2001.

Manuscript received 4 September 2001; accepted 6 September

${ }^{6}$ E-mail: micheli@stanford.edu
$8.0)$, low and variable oxygen concentrations (0-110 $\mu \mathrm{mol} / \mathrm{L})$, and normally toxic levels of sulfides and heavy metals (Johnson et al. 1988a, $b, 1994)$. Studies have shown that the morphology, physiology, and development of vent species are unique in many respects (Grassle 1986, Tunnicliffe 1991, Fisher and Childress 1992). In contrast, we know very little about what ecological processes help to structure hydrothermal vent communities (but see Mullineaux et al. 2000).

Environmental conditions at hydrothermal vents are extreme and variable, so abiotic factors are generally thought to be most important in structuring populations and communities, while biological interactions are assumed to play a relatively minor role (Tunnicliffe and Juniper 1990, Van Dover 1995, Luther et al. 2001). However, several characteristics of hydrothermal vent 
communities suggest that biological processes, namely competition, predation, and recruitment, may contribute to structuring communities of vent organisms. Most vent species are found in extremely high densities, generally covering all available surfaces around vents, and all vent species ultimately rely on the same energy source (i.e., sulfides), suggesting that competition for space and perhaps nutrients is intense. Predatory crabs and fish are also found at high densities at hydrothermal vents (Hessler et al. 1988), suggesting that predation may have significant impacts on vent benthic communities. Finally, deep-sea hydrothermal vents are patchy and ephemeral environments, with individual vents lasting only a few years or decades (Hessler et al. 1988, Haymon et al. 1991). Therefore, dispersal and colonization processes must play a key role in maintaining and structuring these communities (Kim et al. 1994, Mullineaux et al. 1998). To date, there has been no direct test of the relative importance of abiotic factors and biotic processes in structuring deep-sea hydrothermal vent communities.

A plethora of field manipulative experiments has shown that the structure and dynamics of intertidal and shallow-water marine communities result from the interplay of abiotic factors and biotic interactions. On temperate rocky shores, algae typically dominate the low-intertidal zone, followed by bands of mussels, barnacles, and finally periwinkle snails at progressively higher intertidal zones (Stephenson and Stephenson 1972). The characteristic patterns of species replacement along gradients of increasing tidal elevation on rocky shores are partly due to the species' differential ability to withstand stresses associated with exposure to air and sunlight (Newell 1976). However, experimental manipulations have shown that physical gradients alone do not explain patterns of species distribution on rocky shores (Menge and Sutherland 1987). Much of the variation in community structure and species composition is due to local biological interactions (Paine 1966, Connell 1972, Underwood and Denley 1984), disturbance regimes (Dayton 1971, Sousa 1979), and to regional variation in the recruitment of pelagic larvae to benthic communities (Gaines and Roughgarden 1985, Roughgarden et al. 1988) and availability of nutrients and patterns of productivity in the nearshore environment (Bustamante et al. 1995).

The relative contribution of competitive and predator-prey interactions to structuring natural communities is predicted to decrease along gradients of increasing environmental harshness (e.g., physical stress associated with exposure to air, temperature extremes, or mechanical disturbance from waves), and to increase along gradients of increasing recruitment intensity (Menge 1976, Menge and Sutherland 1976, 1987, Menge and Farrell 1989). In habitats (or microhabitats) characterized by extreme and fluctuating environmental conditions, physical factors are expected to be most important in limiting population sizes and structuring communities, whereas biotic interactions are expected to play a major role in more benign environments and where recruitment rates are high. At low- and midintertidal elevations of rocky shores, physiological stress is low and organisms often cover all available space if recruitment rates are high. When space is limiting, competitively dominant species can displace competitive inferiors from the most suitable zones along the intertidal gradient, thereby either relegating the competitive inferiors to higher zones, where physical conditions are more extreme, or excluding them altogether (Connell 1972).

Marine predators such as seastars and gastropods feed for longer periods in the low-intertidal than the high-intertidal zone. Consequently, marine predators can influence the structure of benthic intertidal communities by setting the lower limit of distribution of prey, and by selectively removing competitively dominant species, thereby allowing competitive inferiors to persist (Connell 1961, 1972, Paine 1966, Peterson 1979, Menge et al. 1995). Predation also indirectly influences communities in aquatic and terrestrial ecosystems through complex webs of indirect species interactions (Estes and Palmisano 1974, Power 1990, Carpenter and Kitchell 1993, Wootton 1993, Menge 1994). Theoretical models of food-chain interactions along productivity gradients predict that cascading trophic interactions shape communities only when productivity is sufficient to support high biomasses of consumers (Fretwell 1977, Oksanen et al. 1981). Thus, cascading effects of predation may be expected at the most productive end of an environmental productivity gradient.

Recent studies of intertidal plant communities indicate that positive interactions and the amelioration of stressful physical conditions by plant canopies have strong direct effects on intertidal communities by enhancing organism recruitment, growth, and survival at high tidal levels (Bertness and Callaway 1994, Bertness et al. 1999). Thus, positive interactions can play an important role in structuring intertidal marine communities, particularly where environmental conditions are extreme, for example where marine organisms experience prolonged exposure to air, at high intertidal elevation, or wave disturbance on exposed shores.

The conceptual models and generalizations of community organization developed from studies of intertidal and shallow-subtidal marine communities have not been extended to and evaluated in deep-sea communities. Similar to intertidal habitats, hydrothermal vent environments are characterized by high spatial variation in environmental conditions and by large temporal fluctuations in physical variables. Variation in environmental conditions around vents is accompanied by distinct patterns of species replacement over spatial scales of meters to hundreds of meters (Hessler et al. 1988, Johnson et al. 1988a, b). At hydrothermal vents of the East Pacific Rise (EPR), vestimentiferan tube- 
worms (Riftia pachyptila Jones, Tevnia jerichonana Jones, and Oasisia alvinae Jones) inhabit areas with vigorous hydrothermal flows and water temperatures as high as $30^{\circ} \mathrm{C}$. Vent mussels (Bathymodiolus thermophilus Kenk \& Wilson) and clams (Calyptogena magnifica Boss \& Turner) dominate areas of lower venting activity and temperatures $\left(\leq 10^{\circ} \mathrm{C}\right)$. Suspension feeders, such as serpulid polychaetes (Laminatubus alvini Ten Hove \& Zibrowius) and barnacles (Neolepas zevinae Newman), inhabit surrounding areas with water temperatures generally $<2^{\circ} \mathrm{C}$. Areas of the seafloor outside the vent influence experience an ambient water temperature of $1.8^{\circ} \mathrm{C}$ and support low densities of benthic invertebrates, including sparse ophiuroids, sea anemones, and holothurians. Mobile consumer species, including fishes, crabs, octopi, and whelks, are found at high densities around vents (Hessler et al. 1988).

Based on studies of intertidal and shallow-water marine communities, we might predict that vent communities are structured by environmental conditions and possibly by positive interactions where physical conditions are extreme and variable, close to active venting sites (e.g., Mullineaux et al. 2000), whereas the importance of competitive and predator-prey interactions should increase away from vents, where environmental conditions are relatively moderate. Deepsea hydrothermal vents, however, differ from intertidal and shallow-water habitats in some important respects, and one might question whether conceptual models of species interactions developed for other communities apply to these unique environments. First, at hydrothermal vents the most extreme environmental conditions also coincide with the greatest availability of the resources that fuel vent food webs (sulfides). Hydrothermal vent invertebrates exhibit a suite of physiological adaptations that allow them to withstand some of the environmental conditions at active venting sites. "Harsh" conditions close to venting sites may in fact be tolerable to invertebrates endemic to vents, which are capable of persisting under these conditions and utilizing the high resource availability (i.e., sulfides) to attain high biomass. Second, gradients in environmental parameters around vents are created primarily by variation in chemical and physical characteristics of seawater, including sulfide, metals and oxygen concentrations, and water temperature (Johnson et al. $1988 a, b$, 1994). In contrast, mechanical disturbances, such as those produced by tidal currents and by waves in shallow environments, are basically nonexistent around deep-sea vents.

Experimental manipulations are the most promising approach to understanding mechanisms and consequences of species interactions within communities and determining how biotic interactions and abiotic variables act jointly to produce the observed patterns of species distribution (but see Raffaelli and Moller 1999). We used manipulative field experiments to determine whether predation affects the structure of hy-

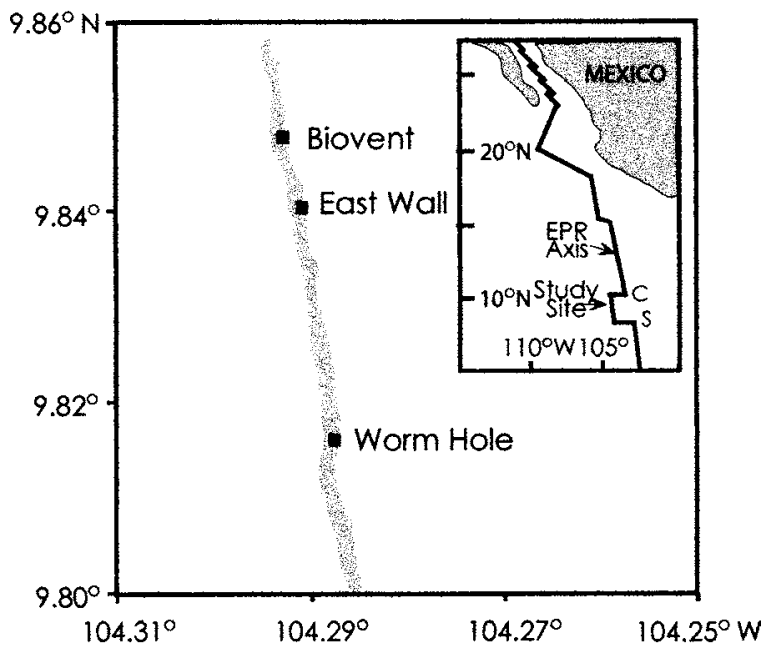

FIG. 1. Map of Biovent, East Wall, and Worm Hole vent sites, located on the axis of the East Pacific Rise (shaded line) near $9^{\circ} 50^{\prime} \mathrm{N}$, between the Clipperton (C) and Sequieros (S) fracture zones.

drothermal vent benthic communities. Specifically, we asked: (1) whether predation affects community structure by influencing the initial establishment (i.e., recruitment and abundance of early life stages) of species; and (2) whether effects of predation on the newly recruited benthic community vary among zones characterized by different environmental conditions around venting sites. We complemented these experiments with in situ observations of the foraging behavior of vent consumers and stomach content analyses of the most common consumers, a zoarcid fish (Thermarces cerberus Rosenblatt \& Cohen), and two crabs (Bythograea thermydron Williams, and Munidopsis subsquamosa Henderson). This study provides direct evidence that biotic interactions play a critical role in shaping deep-sea hydrothermal vent communities and complements the work by Mullineaux et al. (2000) on how biological interactions affect recruitment at vents by showing that predation and abiotic conditions interact to organize vent invertebrate communities.

\section{Methods \\ Study sites and zones}

Experiments were conducted at three sites (East Wall, Biovent, and Worm Hole) along the axial valley on the EPR near $9^{\circ} 50^{\prime} \mathrm{N}$. The geology, geochemistry, and biology of vents located in this area are well described elsewhere (Detrick et al. 1987, Haymon et al. 1991, Lutz et al. 1994, Von Damm et al. 1995). East Wall is located at $9^{\circ} 50.54^{\prime} \mathrm{N}, 104^{\circ} 17.52^{\prime} \mathrm{W}$, Biovent at $9^{\circ} 51.96^{\prime} \mathrm{N}, 104^{\circ} 17.62^{\prime} \mathrm{W}$, and Worm Hole at $9^{\circ} 49.07^{\prime} \mathrm{N}, 104^{\circ} 17.30^{\prime} \mathrm{W}$ (Fig. 1). Water depths at these sites ranged between 2505 and $2515 \mathrm{~m}$. At each site, we distinguished four faunal zones located along a gradient of decreasing exposure to flux of vent fluids. 
Zonal boundaries were based on the dominant benthic invertebrates occupying hard-substrate (basalt) seafloor and the water temperature, which acts as a proxy for concentrations of the suite of chemical and biological constituents of venting fluids (Johnson et al. 1988a, 1994). The lateral extent of faunal zones varied substantially within and among vent sites, ranging from patches of $<1 \mathrm{~m}$ in diameter to more continuous bands of hundreds of meters. The vestimentiferan zone was dominated by the vestimentiferan tubeworms Riftia pachyptila, at Biovent and East Wall, and Tevnia jerichonana at Worm Hole, and was characterized by areas with shimmering diffuse hydrothermal flows and water temperatures ranging from $1.5^{\circ}$ to $30^{\circ} \mathrm{C}$. The bivalve zone was dominated by the vent mussel (Bathymodiolus thermophilus) and characterized by lower hydrothermal flows, with temperatures ranging from $1.5^{\circ}$ to $10^{\circ} \mathrm{C}$. The suspension-feeder zone comprised beds of serpulid polychaete worms (Laminatubus alvinae), with water temperatures generally $<2^{\circ} \mathrm{C}$. The bivalve and the serpulid zones were well developed and easily distinguishable at Biovent and East Wall. However, the vestimentiferan zone at Biovent was often also heavily colonized by mussels. At Worm Hole, there were no extensive mussel beds, only clusters of juvenile mussels scattered among the serpulid worms throughout the suspension-feeder zone. Finally, the periphery zone contained no dense assemblage of benthic invertebrates and was characterized by the ambient water temperature $\left(1.8^{\circ} \mathrm{C}\right)$.

\section{Predator-exclusion experiments}

To determine whether vent predators influence the establishment and structure of natural assemblages of benthic invertebrates at hydrothermal vents, we conducted 5- and 8-mo-long predator-exclusion experiments using the deep-sea submersible ALVIN. The 8mo experiment was conducted at East Wall, beginning in April 1995. Similar 5-mo experiments were conducted at all three sites to determine the generality of results obtained from the 8-mo experiment. For the 5mo experiment, recruitment substrates were deployed in November 1994 and retrieved in April 1995. All experiments relied on the deployment of clean recruitment substrates (basalt cubic blocks, roughly $10 \mathrm{~cm}$ on each side) within each of the distinct faunal zones at each site. Basalt blocks (Interstate Rock Products, Washougal, Washington, USA) had rough, unpolished surfaces similar to the texture of natural basalt rocks at ridge crests. To determine the impact of predation, the recruitment blocks were placed inside, or outside of, cubic mesh cages $20 \times 20 \times 20 \mathrm{~cm}$ constructed of plastic Vexar mesh (6-mm mesh size; Internet, Incorporated, Minneapolis, Minnesota, USA) reinforced by a frame of $1.1 \mathrm{~cm}$ diameter PVC pipes, designed to exclude the larger ( $>6 \mathrm{~mm}$ in smallest dimension) local predators, mainly fish, crabs, whelks, and octopus. To assess whether cages caused experimental artifacts, for example by modifying water flows around blocks and/ or providing additional structure for animal recruitment, we deployed an additional set of blocks (a third block treatment) within cage controls. Cage controls were identical to full cages except for one missing side. Cage controls were used in the 8-mo but not in the 5mo experiment. For the 8-mo experiment, three replicate sets of one uncaged block, one cage, and one cage control (a "block group") were deployed within each of the four zones at the East Wall site (36 total recruitment blocks). For the 5-mo experiment, three replicate sets of one caged and one uncaged block were placed within each of the four zones at East Wall and Biovent, and within the three zones at Worm Hole (the bivalve and suspension-feeder zones were undistinguishable at this site, see Study sites and zones; 66 total recruitment blocks).

After 5 or 8 mo on the seafloor, recruitment blocks were recovered and placed in separate, solid-walled recovery boxes on ALVIN. Recovery boxes had lids that were closed shut after each block was placed in the box to prevent the recruits from escaping or being lost during ascent. All animals on blocks, and those that fell from blocks into the recovery boxes during the ascent to the surface and were subsequently retained by a $1-\mathrm{mm}$ sieve, were counted and identified to the lowest possible taxonomic level. Upon deployment and recovery, water temperatures were measured beneath each block with the ALVIN temperature probe.

\section{Feeding-preference experiments}

Feeding-preference experiments were conducted by deploying an array of common vent invertebrates onto the seafloor near well-established vent communities. The identities, activities and locations of all consumers attracted to the array were then recorded using an automated time-lapse still camera system. Feeding-preference experiments were conducted in the vestimentiferan zone of East Wall. A "smorgasbord" array of invertebrates potentially eaten by vent consumers was constructed by securing dead individuals of the vestimentiferan Riftia pachyptila, the mussel Bathymodiolus thermophilus, and the limpet Lepetodrilus elevatus, as well as a non-vent clam species (Megapitaria squalida Sowerby), as a control lacking toxic constituents, to a $85 \times 71 \mathrm{~cm}$ piece of plastic mesh, reinforced by a flexible frame constructed with $5 \mathrm{~cm}$ wide PVC strips. Organisms were immediately frozen upon recovery from the submersible, and later attached to the smorgasbord frame just prior to its deployment in the field.

To control for a possible effect of food availability on consumer choice, we offered equal numbers of each food type, except for limpets, where larger numbers were used because of their small size. For each trial, we attached to the smorgasbord frame 3 mussels (7.5$11.5 \mathrm{~cm}$ in shell height), 3 Riftia $(1-1.5 \mathrm{~cm}$ in tube diameter) cut into pieces of similar length $(8-13 \mathrm{~cm}$ length), 3 clams (5.5-7.5 cm in shell length), and 60 
limpets $(0.6-1.0 \mathrm{~cm}$ in shell length). In addition, we attached 3 pieces of empty Riftia tubes to determine whether consumers are attracted to biogenic structure, and 3 Riftia with half of their tubes removed to determine whether external tubes deter consumption of Riftia. L. elevatus are commonly attached to the tubes of Riftia, so limpets were presented to consumers both alone $(n=60)$ and in association with Riftia tubes ( $n$ $=60$ ) to determine whether attachment to tubes influences the susceptibility of limpets to predation. We included the non-vent clam Megapitaria squalida to determine whether the high sulfur levels in the tissues of vent species (Fisher and Childress 1992) deter predators. Groups of prey belonging to the same species were regularly spaced on the prey array ( $\sim 25 \mathrm{~cm}$ apart $)$ and their location was assigned at random.

Before deployment, the food array, with food already attached, was rolled up and placed in a plastic cylinder fitted to the still camera system. On the seafloor, ALVIN maneuvered the camera system into position on a section of horizontal rock surface near the vestimentiferan zone, removed the food array from the sheath on the camera system, unrolled it, and placed it beneath the camera within its field of view. The camera system took pictures of the positions of consumers on the array at 15-s (during the first experimental trial) or 1-min (second trial) intervals, for a total duration of 3.5 and $24 \mathrm{~h}$ respectively. To standardize results across the two experimental trials, we used only images taken at 1min intervals for the first $3.5 \mathrm{~h}$ of each trial. The 200 images produced during each trial were analyzed by recording the identity and location of all consumers on the food array. Because invertebrates offered to vent consumers in this choice experiment were dead, this assay tests for consumer scavenging preferences rather than predatory choices.

\section{Stomach content analyses}

To help infer trophic relations among vent species, stomach contents of the most abundant consumers in the study area were collected and analyzed. A total of 8 zoarcid fishes (Thermarces cerberus), 4 brachyuran crabs (Bythograea thermidron), and 7 galatheid crabs (Munidopsis subsquamosa) were captured at different zones of the East Wall and Biovent sites using a suction device attached to a rotating multi-chamber collector on ALVIN. Animals were dissected as soon as they were brought to the surface, and the contents of their stomachs and intestines were examined under a binocular dissecting microscope. Recognizable food items were identified to species.

\section{Statistical analyses}

To determine the effects of biological zone and predator exclusion on community development, we compared the total abundance and species richness of invertebrates on recruitment blocks in the 8-mo experiment using nested ANOVAs, with zone (vestimenti- feran, bivalve, suspension-feeder, and periphery zones) and treatment (uncaged blocks, caged blocks, and cage controls) as the main fixed factors (crossed), and block groups (each group of one uncaged block, one caged block, and one cage control) nested within zone. We compared the total abundance and species richness of the invertebrates for the 5-mo experiment using a similar nested ANOVA model, except that there was no cage control used in this experiment. For the 5-mo experiment, we conducted separate analyses for each of the three sites. Site was not included as a factor in the ANOVAs because the species' patterns of zonation differed among the three sites (see Study sites and zones). In particular, zonal boundaries among the vestimentiferan-, bivalve-, and suspension-feeder-dominated bands were obvious at East Wall, while the vestimentiferan zone contained several mussel clumps at Biovent and the bivalve zone was not well developed at Worm Hole. In all experiments, there were three replicate blocks for each treatment combination except for the bivalve zone in the 8-mo experiment, where only two uncaged blocks were recovered. To determine whether biological zone and block treatment influenced the species composition of communities on recruitment blocks in the 5- and 8-mo experiments, we used MANOVA comparing the total number of animals within two functional groups, mobile and sessile species. Sessile species included mussels, tubiculous polychaetes, vestimentiferan tubeworms, barnacles, and other sedentary organisms that were found attached to the blocks. Mobile species included various species of snails, limpets, crustaceans, and polychaetes, and were found on the blocks or unattached and retained in the recovery boxes. The MANOVAs had the same combinations of main and nested factors as those used for total abundance and species richness. We used univariate ANOVAs to test the effect of those factors that were significant in the MANOVAs on the abundance of mobile and sessile species. We also used ANOVA to determine the independent and joint effects of biological zone and caging treatment on the proportion of mobile species to examine how these factors influenced the relative contribution of mobile species to total abundances. Before ANOVAs and MANOVAs, we used Cochran's tests (at $\alpha=0.05$ ) to test for homogeneity of variances and used square root-, log- or arcsine-transformation of the data when needed. We compared treatment means after ANOVAs using Tukey's post hoc comparisons (at $\alpha=0.05$ ).

Principal Component Analysis (PCA) was used to determine which species explained most of the variation in community composition among recruitment blocks. For PCA, we retained only species that were represented in the samples by $>50$ individuals and that were found in $>1$ sample. Abundances of the species that explained most of the variation among blocks, based on PCA, were then compared among biological zones and treatments using the nested ANOVA model 
TABle 1. Temperature anomalies $\left({ }^{\circ} \mathrm{C}\right.$ above ambient $1.8^{\circ} \mathrm{C}$ temperature; mean $\left.\pm 1 \mathrm{SE}\right)$ measured underneath experimental blocks deployed within four faunal zones (vestimentiferan, bivalve, suspension-feeder, and periphery zone) at three locations (East Wall, Biovent, and Worm Hole) near $9^{\circ} 50^{\prime}$ on the East Pacific Rise, at the beginning and the end of experiments.

\begin{tabular}{lcccc}
\hline \hline \multirow{2}{*}{ Site } & \multicolumn{4}{c}{ Zone } \\
\cline { 2 - 5 } East Wall & Vestimentiferan & Bivalve & Suspension & Periphery \\
\cline { 2 - 5 } Biovent & $4.02 \pm 0.5$ & $1.66 \pm 0.4$ & $0.11 \pm 0.06$ & 0 \\
& $(0.7-13.2)$ & $(0-5.6)$ & $(0-0.9)$ & \\
Worm Hole & $9.45 \pm 1.6$ & $2.35 \pm 0.48$ & $0.13 \pm 0.13$ & 0 \\
& $(2.4-22.7)$ & $(0-5.7)$ & $(0-1.7)$ & 0 \\
& $5.14 \pm 0.71$ & \multicolumn{2}{c}{$0.72 \pm 0.22$} \\
$(0.1-9.4)$ & \multicolumn{2}{c}{$(0-3.2)$} & \\
\hline
\end{tabular}

Notes: Listed are mean and (in parentheses) minimum and maximum temperature anomalies recorded within each zone at the three sites. The bivalve and suspension-feeder zones were indistinguishable at Worm Hole (see Methods).

described above. For the feeding-preference experiments, we compared the total number of observations of consumers feeding on the various food items using $\chi^{2}$ tests.

\section{RESULTS}

Study sites and zones: temperature anomalies

Water temperature anomalies (degrees Celsius above ambient temperature) measured at the experimental blocks deployed at the three sites indicated that blocks in the vestimentiferan zone were exposed to the greatest mean temperature and range of temperatures, with mean temperatures $4^{\circ}-9.5^{\circ} \mathrm{C}$ above ambient, and maximum temperatures $9.4^{\circ}-22.7^{\circ} \mathrm{C}$ above ambient (Table 1 ). In the bivalve and suspension-feeder zones, temperatures were only slightly above ambient (mean $1.6^{\circ}-$ $2.3^{\circ} \mathrm{C}$ above ambient in the bivalve zone, $<1^{\circ} \mathrm{C}$ above ambient in the suspension-feeder zone) and fluctuated within narrower ranges, reaching maximum temperatures $5.7^{\circ}$ and $3.2^{\circ} \mathrm{C}$ above ambient, respectively (Table $1)$. No temperature anomalies appeared in the periphery zone (Table 1).

\section{Eight-month caging experiment}

A total of 51 taxa (species or species groups) recruited to the blocks over the course of the 8-mo experiment (Table 2), including all the dominant benthic invertebrate species of the hydrothermal vents of the EPR (Desbruyères and Segonzac 1997): the vestimentiferan worms Riftia pachyptila and Tevnia jerichonanalOasisia alvinae (these two species were indistinguishable as juveniles; Table 2), the vent mussel Bathymodiolus thermophilus, and the serpulid worm Laminatubus alvini. ANOVA revealed that biological zone and caging treatment interacted in their influence on total abundance of benthic invertebrates (Table 3). Caging affected benthic invertebrates only in the vestimentiferan zone, where abundance was greater within cages than on uncaged blocks, and intermediate and not significantly different from caged or uncaged blocks in cage controls (Fig. 2A). For all three caging treatments (blocks, cages, cage controls), total abundance of invertebrates declined with decreasing exposure to venting fluids: abundance was 14-275 times greater in the vestimentiferan zone than in any other zone, lowest in the periphery, and intermediate in the bivalve and the suspension-feeder zones (Fig. 2A).

The taxon richness (i.e., the number of species or species groups found on blocks, not including unidentified specimens) of the community that developed on the blocks in the 8-mo experiment varied significantly among biological zones (Table 3), with zone explaining $61.5 \%$ of the variability in this response variable. Taxon richness did not differ among the vestimentiferan, bivalve, and suspension-feeder zones, averaging 10.313.9 taxa on blocks deployed within these zones, but was significantly lower in the periphery than in all other zones (Fig. 2B). Caging treatment had no detectable influence on taxon richness and did not show an interaction with zone (Table 3). Taxon richness varied significantly among block groups within each zone, accounting for $19 \%$ of the total variability (Table 3 ).

MANOVA revealed that community composition (defined as the ordered pair of densities of mobile and sessile invertebrates) varied with biological zone and caging treatment, and their interaction (Table 4). ANOVA indicated that caging treatment affected the abundance of mobile species, but the effect varied with zone (Table 4). In the vestimentiferan zone, abundances of mobile species (dominated by limpets, snails, small crustaceans, and some polychaetes; Table 2) were higher inside cages than on uncaged blocks. Abundances of mobile species inside cage controls were not significantly different from either uncaged or caged blocks (Fig. 3B). In no other zone did caging treatment detectably affect abundances of mobile species (Fig. 3B). Abundance of sessile species (dominated by vestimentiferan worms, gastropod postlarvae, tubiculous polychaetes, and bivalves; Table 2) varied only with zone (Table 4). Abundances were higher in the vestimenti- 
TABLE 2. Invertebrate taxa (species or species groups) that colonized the recruitment surfaces in the 8-mo caging experiment conducted at East Wall are listed.

\begin{tabular}{|c|c|c|c|c|}
\hline Taxon & $\begin{array}{l}\text { Order, class, } \\
\text { or phylum }\end{array}$ & $\begin{array}{l}\text { Mobile }(\mathrm{m}) \\
\text { or } \\
\text { sessile }(\mathrm{s}) ?\end{array}$ & $\begin{array}{l}\text { Total no. } \\
\text { individuals }\end{array}$ & $\begin{array}{c}\text { No. samples } \\
\text { (total: } \\
N=35)\end{array}$ \\
\hline Cyathermia naticoides & Gastropoda & $\mathrm{m}$ & 7386 & 7 \\
\hline Lepetodrilus elevatus & Gastropoda & $\mathrm{m}$ & 6023 & 22 \\
\hline Amphipods & Crustacea & $\mathrm{m}$ & 1573 & 21 \\
\hline Juvenile vestimentiferans & Vestimentifera & $\mathrm{s}$ & 1190 & 8 \\
\hline Gastropod postlarvae & Gastropoda & $\mathrm{s}$ & 904 & 14 \\
\hline Amphisamytha galapagensis & Polychaeta & $\mathrm{s}$ & 869 & 22 \\
\hline Lepetodrilus pustulosus & Gastropoda & $\mathrm{m}$ & 545 & 11 \\
\hline Juvenile limpets & Gastropoda & $\mathrm{m}$ & 518 & 10 \\
\hline Abyssotherma pacifica & Foraminifera & $\mathrm{s}$ & 434 & 26 \\
\hline Ophryotrocha akessoni & Polychaeta & $\mathrm{m}$ & 372 & 23 \\
\hline Archinome rosacea & Polychaeta & $\mathrm{m}$ & 276 & 16 \\
\hline Clypeosectus delectus & Gastropoda & $\mathrm{m}$ & 227 & 12 \\
\hline Paralvinella sp. & Polychaeta & $\mathrm{s}$ & 123 & 6 \\
\hline Bathymargarites symplector & Gastropoda & $\mathrm{m}$ & 113 & 11 \\
\hline T. jerichonana/O. alvinae & Vestimentifera & $\mathrm{s}$ & 99 & 5 \\
\hline Bathymodiolus thermophilus & Bivalvia & $\mathrm{s}$ & 86 & 12 \\
\hline Laminatubus alvini & Polychaeta & $\mathrm{s}$ & 85 & 14 \\
\hline Lepetodrilus ovalis & Gastropoda & $\mathrm{m}$ & 67 & 15 \\
\hline Gorgoleptis spiralis & Gastropoda & $\mathrm{m}$ & 54 & 8 \\
\hline Polynoid polychaetes & Polychaeta & $\mathrm{m}$ & 45 & 15 \\
\hline Eulepetopsis vitrea & Gastropoda & $\mathrm{m}$ & 37 & 14 \\
\hline Riftia pachyptila & Vestimentifera & s & 35 & 4 \\
\hline Ophiuroids & Echinodermata & $\mathrm{m}$ & 31 & 8 \\
\hline Tanaids & Crustacea & $\mathrm{m}$ & 29 & 7 \\
\hline Lepetodrilus cristatus & Gastropoda & $\mathrm{m}$ & 27 & 6 \\
\hline Isopods & Crustacea & $\mathrm{m}$ & 24 & 2 \\
\hline Bythograea thermydron & Crustacea & $\mathrm{m}$ & 18 & 6 \\
\hline Brown papillated worms & Polychaeta & $\mathrm{m}$ & 10 & 7 \\
\hline Iphionella risensis & Polychaeta & $\mathrm{m}$ & 9 & 6 \\
\hline Leptostracans & Crustacea & $\mathrm{m}$ & 7 & 3 \\
\hline Bathypecten vulcani & Bivalvia & $\mathrm{s}$ & 7 & 6 \\
\hline Nemertean worms & Nemertinea & $\mathrm{m}$ & 6 & 3 \\
\hline Juvenile polychaetes & Polychaeta & $\mathrm{m}$ & 6 & 5 \\
\hline Branchipolynoe sp. & Polychaeta & $\mathrm{m}$ & 5 & 4 \\
\hline Gorgoleptis emarginatus & Gastropoda & $\mathrm{m}$ & 5 & 1 \\
\hline Hesiospina vestimentifera & Polychaeta & $\mathrm{m}$ & 5 & 1 \\
\hline Aplacophorans & Aplacophora & $\mathrm{m}$ & 4 & 4 \\
\hline Nereis sp. & Polychaeta & $\mathrm{m}$ & 4 & 3 \\
\hline Anemones & Coelenterata & $\mathrm{s}$ & 3 & 3 \\
\hline Neolepas zevinae & Crustacea & $\mathrm{s}$ & 3 & 1 \\
\hline Misc. benthic foraminiferans & Foraminifera & $\mathrm{s}$ & 3 & 2 \\
\hline Hesionid polychaetes & Polychaeta & $\mathrm{m}$ & 2 & 2 \\
\hline Provanna sp. & Gastropoda & $\mathrm{m}$ & 2 & 2 \\
\hline Spionid polychaetes & Polychaeta & $\mathrm{m}$ & 2 & 2 \\
\hline Dorvilleid polychaete & Polychaeta & $\mathrm{m}$ & 1 & 1 \\
\hline Calyptogena magnifica & Bivalvia & $\mathrm{s}$ & 1 & 1 \\
\hline Barnacle cyprid & Crustacea & $\mathrm{m}$ & 1 & 1 \\
\hline Depressigyra planispira & Gastropoda & $\mathrm{m}$ & 1 & 1 \\
\hline Glycera sp. & Polychaeta & $\mathrm{m}$ & 1 & 1 \\
\hline Peltospira delicata & Gastropoda & $\mathrm{m}$ & 1 & 1 \\
\hline
\end{tabular}

Notes: A total of 36 blocks were deployed, but one block was lost from the bivalve zone $(n$ $=35)$. Taxa were assigned to one of two categories: mobile $(\mathrm{m})$ or sessile $(\mathrm{s})$ species. The total number of individuals and the number of samples containing individuals are reported for each taxon. Gastropods were by far the most common group (total no. individuals $=15910$ ), followed by polychaetes (total $=1815)$, crustaceans (total $=1655)$, and vestimentiferan tubeworms (total $=1324)$. Tevnia jerichonana and Oasisia alvinae were morphologically indistinguishable as juveniles.

feran zone, lowest in the periphery, and intermediate in the bivalve and suspension-feeder zones (Fig. 3B). Abundances of sessile invertebrates were 1.8-2.3 times greater on uncaged blocks than inside predator exclusion cages (Fig. 3B), but this trend was not statistically significant (Table 4).
ANOVA conducted on the proportion of mobile species confirmed that the relative contribution of mobile species to total abundances was increased by the caging treatment (Table 4). Proportion of mobile species varied with caging treatment, with no significant effect of zone and no interaction between zone and caging (Table 
TABLE 3. ANOVAs comparing total abundance and species richness among different zones (vestimentiferan, bivalve, suspension-feeder, and periphery zone) and treatments (uncaged blocks, cages, and cage controls) in the 8-mo experiment conducted at East Wall.

\begin{tabular}{|c|c|c|c|c|c|c|c|}
\hline \multirow[b]{2}{*}{ Source } & \multirow[b]{2}{*}{ df } & \multicolumn{3}{|c|}{ Abundance } & \multicolumn{3}{|c|}{ Species richness } \\
\hline & & MS $\dagger$ & $F$ & $P$ & MS $\dagger$ & $F$ & $P$ \\
\hline Zone & 3 & 2755.9 & 38.3 & 0.0001 & 237.2 & 8.5 & 0.007 \\
\hline Treatment & 2 & 172.5 & 3.9 & 0.04 & 9.4 & $\begin{array}{l}0.5 \\
1.2\end{array}$ & 0.33 \\
\hline Interaction & 6 & 196.2 & 4.5 & 0.009 & 8.3 & 1.1 & 0.42 \\
\hline Block group(zone) & 8 & 71.9 & 1.6 & 0.20 & 27.9 & 3.6 & 0.02 \\
\hline Residual & 15 & 43.9 & & & 7.8 & & \\
\hline Total sum of squares & 34 & 11753.1 & & & 1157.0 & & \\
\hline
\end{tabular}

$\dagger$ Except in last row, where the total sum of squares is reported.

4). Similar to absolute abundances of mobile species, proportions of mobile species were significantly greater in cages than uncaged blocks, while cage controls were intermediate and not significantly different from either cages or uncaged blocks (Tukey's test).
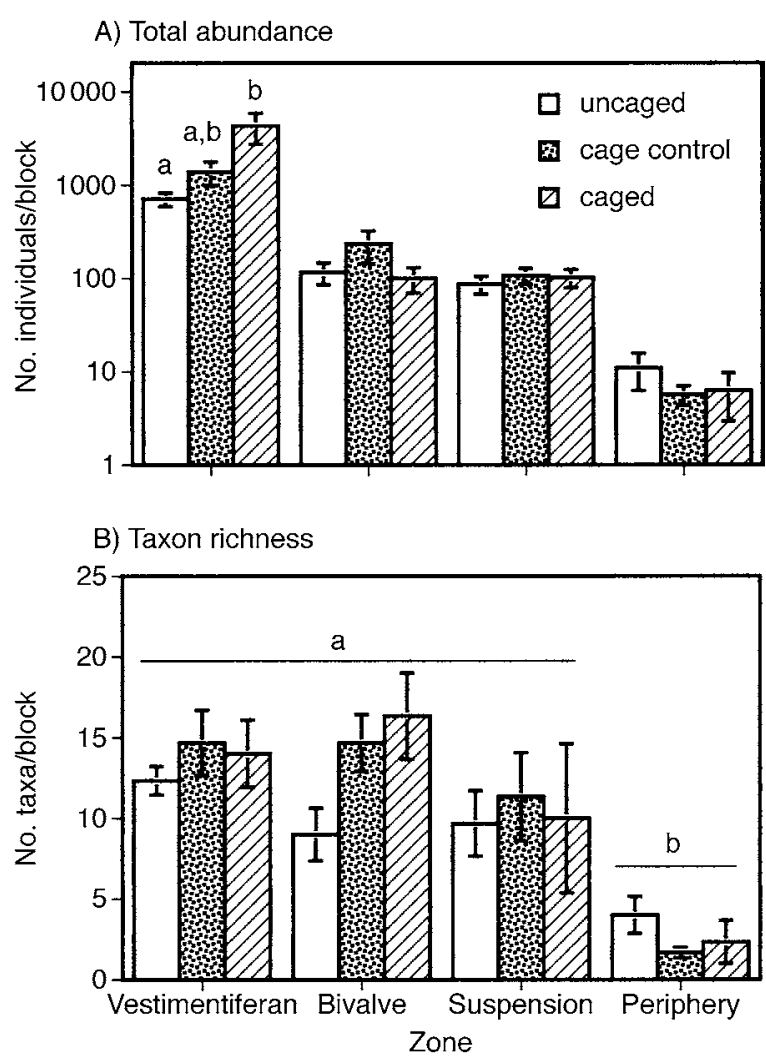

FIG. 2. Patterns of (A) total abundance and (B) species richness of the invertebrate community that developed on recruitment blocks during the 8-mo experiment conducted at East Wall with three experimental treatments (uncaged, caged, and cage controls) within each of four zones (vestimentiferan, bivalve, suspension-feeder, and periphery zone; $n=2-3$ blocks within each zone). Bars are means $\pm 1 \mathrm{SE}$. Bars marked with different letters were significantly different at $\alpha=0.05$ (Tukey's test). Caging treatment had a significant effect on total abundance only in the vestimentiferan zone (A), whereas it had no significant effects on species richness (B). Note log scales on $y$-axis in panel (A).
PCA of the 18 most common taxa in the dataset indicated that only a few species drove the community patterns observed in the 8-mo experiment. The absolute values of the loadings for each taxon (Table 5) reveal that most of the variation was explained by variability in the abundance of two common gastropod species endemic to vents, the limpet Lepetodrilus elevatus and the snail Cyathermia naticoides (Waren \& Bouchet). The first 2 PC axes, explaining $84.6 \%$ of the total variance, had the highest correlation with abundances of C. naticoides (positively correlated to PC1 and negatively correlated to PC2; Table 5) and L. elevatus (positively correlated to both PC axes; Table 5). PC3 explained an additional $4.5 \%$ of the total variance and had the highest, positive correlation with vestimentiferan abundance (Table 5). PC2 was also weakly correlated to the abundance of amphipod crustaceans, the tubiculous polychaete Amphisamytha galapagensis Zottoli, the limpet Lepetodrilus pustulosus, and miscellaneous unidentified juvenile gastropods (Table 5).

Separate univariate ANOVAs conducted on the abundance of each of the six taxa that had the highest correlation with the first three PC axes (Lepetodrilus elevatus, Cyathermia naticoides, vestimentiferans, amphipods, Amphisamytha galapagensis, and Lepetodrilus pustulosus) indicated an effect of zone for each species except $C$. naticoides (Table 6). For all six taxa, abundances were greatest in the vestimentiferan zone (Fig. 4). Although the effect of zone was not statistically significant for $C$. naticoides, this species was found only on blocks recovered from the vestimentiferan zone (Fig. 4). Caging effects were detectable only for L. elevatus, through an interaction with zone (Table 6). L. elevatus was 3-7 times more abundant within cages than in cage controls or on uncaged blocks in the vestimentiferan zone, but abundances were much lower and did not differ detectably among treatments in the other zones (Fig. 4). Caging had no significant effects on abundance of all other species (Table 6).

\section{Five-month caging experiments}

Results of the 5-mo caging experiments conducted at three locations (Fig. 1) revealed trends similar to the 8-mo experiment. At East Wall, total invertebrate abun- 
TABLE 4. MANOVA and ANOVAs comparing the abundance of mobile (m) and sessile (s) species, and proportions of mobile species (after arcsine transformation) among zones (vestimentiferan, bivalve, suspension-feeder, and periphery zone) and treatments (uncaged blocks, cages, and cage controls) in the 8-mo experiment conducted at East Wall.

\begin{tabular}{|c|c|c|c|c|c|c|c|c|c|c|c|c|c|}
\hline \multirow[b]{4}{*}{ Source } & \multirow[b]{4}{*}{ df } & \multicolumn{9}{|c|}{ Univariate ANOVAs } & \multirow{2}{*}{\multicolumn{3}{|c|}{$\begin{array}{c}\text { MANOVA } \\
(\mathrm{m}, \mathrm{s})\end{array}$}} \\
\hline & & \multirow{2}{*}{\multicolumn{3}{|c|}{$\begin{array}{l}\text { Mobile species } \\
(\mathrm{m})\end{array}$}} & \multirow{2}{*}{\multicolumn{3}{|c|}{$\begin{array}{c}\text { Sessile species } \\
\text { (s) }\end{array}$}} & \multirow{2}{*}{\multicolumn{3}{|c|}{$\begin{array}{l}\text { Proportion of } \\
\text { mobile species }\end{array}$}} & & & \\
\hline & & & & & & & & & & & Wilks' & & \\
\hline & & MS† & $F$ & $P$ & $\mathrm{MS} \dagger$ & $F$ & $P$ & $\mathrm{MS} \dagger$ & $F$ & $P$ & lambda & $F$ & $P$ \\
\hline Zone & 3 & 2471.7 & 41.6 & 0.0001 & 284.6 & 19.1 & 0.0005 & 0.3 & 1.6 & 0.25 & 0.03 & 10.7 & 0.0002 \\
\hline Treatment & 2 & 283.5 & 7.1 & 0.007 & 14.5 & 1.1 & 0.35 & 0.3 & 4.2 & 0.03 & 0.39 & 4.2 & 0.008 \\
\hline Interaction & 6 & 210.7 & 5.3 & 0.004 & 2.1 & 0.2 & 0.98 & 0.02 & 0.4 & 0.89 & 0.27 & 2.1 & 0.05 \\
\hline Block group(zone) & 8 & 59.3 & 1.5 & 0.24 & 14.9 & 1.2 & 0.38 & 0.2 & 2.6 & 0.05 & 0.37 & 1.1 & 0.37 \\
\hline Residual & 15 & 39.9 & & & 12.9 & & & 0.07 & & & & & \\
\hline Total sum of squares & 34 & 11298.2 & & & 11257.3 & & & 4.2 & & & & & \\
\hline
\end{tabular}

Note: Wilks' lambda was used to test significance in MANOVA.

$\dagger$ Except in last row, where the total sum of squares is reported.

dance differed among zones but not among caging treatments (Table 7). Abundances were greatest in the vestimentiferan zone and declined away from vents (Fig. 5). At Worm Hole and Biovent, effects of caging

\section{A) Mobile species}

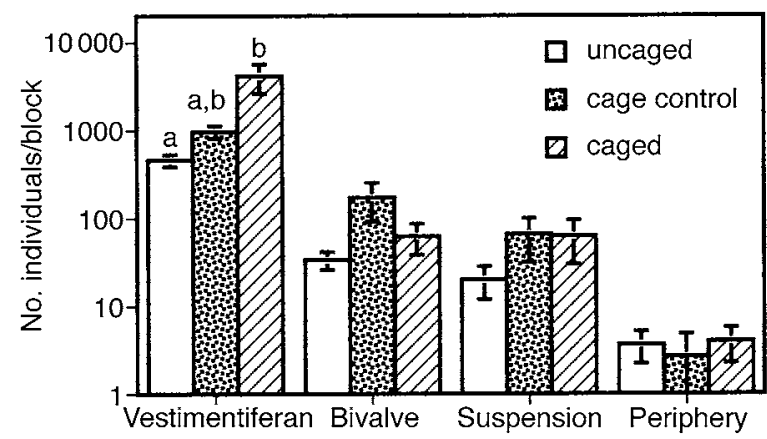

B) Sessile species

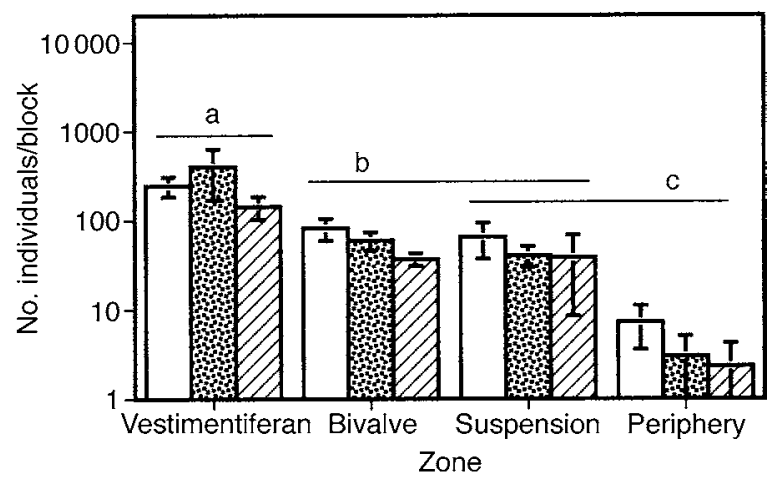

FIG. 3. Patterns of abundance of (A) mobile and (B) sessile species on recruitment blocks during the 8-mo experiment conducted at East Wall, with three experimental treatments (uncaged, caged, and cage controls) within each of four zones (vestimentiferan, bivalve, suspension-feeder, and periphery zone; $n=2-3$ blocks within each zone). Bars are means \pm $1 \mathrm{SE}$. Bars marked with different letters were significantly different at $\alpha=0.05$ (Tukey's test). Caging treatment had a significant effect on mobile species abundance only in the vestimentiferan zone (A), whereas it had no significant effects on sessile species abundance (B). Note log scales on $y$-axes. varied with zone (Table 7). Predator exclusion affected total abundance within the vestimentiferan and bivalve/ suspension-feeder zones at Worm Hole, and in the vestimentiferan zone at Biovent (Table 7 and Fig. 5). At all sites, abundances were greater on caged than on uncaged blocks (Fig. 5), although this trend was not statistically significant at East Wall (Table 7). Taxon richness varied among zones at all sites (Table 7). Taxon richness was greater in the vestimentiferan than in the other zones at Biovent, and was lower in the periphery than in the other zones at East Wall and Worm Hole (Fig. 5). At Worm Hole, species richness also responded to caging (Table 7): predator exclusion resulted in greater species richness compared to uncaged blocks in all zones (Fig. 5).

MANOVAs revealed that community composition in the 5-mo experiments varied with biological zone at East Wall, with the interaction between zone and caging treatment at Biovent, and with zone and caging treatment, but not their interaction, at Worm Hole (Table 8). At East Wall, mobile species had the greatest abundance in the vestimentiferan zone, whereas abundances did not differ significantly among the other zones (Fig. 6). Sessile species showed a similar pattern of greater abundance in the vestimentiferan than in the other zones, though this trend was not significant (Table 8). There was a trend for a greater abundance of mobile species in caged than uncaged blocks, but this trend was not significant (Fig. 6 and Table 8). At Biovent, caging had significant effects on the abundance of mobile and sessile species in the vestimentiferan but in no other zone (Tukey's tests; Fig. 6). In the vestimentiferan zone, mobile species were more abundant in cages than on uncaged blocks, whereas the opposite was true for sessile species (Fig. 6). At Worm Hole, caging caused greater abundances of mobile species in all zones (Table 8 and Fig. 6). Mobile species abundances were greatest in the vestimentiferan zone, intermediate in the bivalve/suspension-feeder zone (the two zones were indistinguishable at this site; see Meth$o d s$ ), and lowest in the periphery zone (Fig. 6). Abun- 
TAble 5. Principal Component Analysis performed on the 18 most common taxa in the 8mo caging experiment conducted at East Wall.

\begin{tabular}{lccc}
\hline \hline \multicolumn{1}{c}{ Taxon } & PC1 & PC2 & PC3 \\
& $(58.6 \%)$ & $(26.0 \%)$ & $(4.5 \%)$ \\
\hline Cyathermia naticoides $(\mathrm{m})$ & 0.722 & -0.619 & -0.117 \\
Lepetodrilus elevatus $(\mathrm{m})$ & 0.577 & 0.477 & -0.305 \\
Vestimentiferans (s) & 0.232 & 0.007 & 0.872 \\
Amphipods (m) & 0.183 & 0.366 & 0.187 \\
Lepetodrilus pustulosus $(\mathrm{m})$ & 0.135 & 0.211 & 0.031 \\
Juvenile limpets (m) & 0.106 & 0.224 & -0.028 \\
Gastropod postlarvae (s) & 0.102 & 0.298 & -0.074 \\
Paralvinella sp. (s) & 0.086 & -0.017 & 0.131 \\
Amphisamytha galapagensis $(\mathrm{s})$ & 0.059 & 0.210 & 0.161 \\
Ophryotrocha akessoni $(\mathrm{m})$ & 0.032 & 0.105 & -0.056 \\
Bathymodiolus thermophilus $(\mathrm{s})$ & 0.029 & 0.085 & 0.002 \\
Laminatubus alvini $(\mathrm{s})$ & 0.013 & 0.073 & -0.101 \\
Lepetodrilus ovalis $(\mathrm{m})$ & 0.007 & 0.032 & -0.039 \\
Gorgoleptis spiralis $(\mathrm{m})$ & -0.010 & 0.006 & -0.055 \\
Archinome rosacea $(\mathrm{m})$ & -0.015 & 0.037 & -0.081 \\
Bathymargarites symplector $(\mathrm{m})$ & -0.025 & -0.020 & -0.054 \\
Clypeosectus delectus $(\mathrm{m})$ & -0.035 & -0.028 & -0.086 \\
Foraminiferans $(\mathrm{s})$ & -0.052 & -0.023 & -0.115 \\
\hline
\end{tabular}

Notes: Taxa were either mobile $(\mathrm{m})$ or sessile $(\mathrm{s})$. The eigenvectors for the first three PC axes are reported. The proportion of the total variance explained by each PC axis is given in parentheses.

dances of sessile species tended to be greater in the vestimentiferan and bivalve/suspension-feeder zones than in the periphery zone (Fig. 6), but this pattern was not significant.

\section{Feeding-preference experiments}

The food array used in the feeding-preference experiments attracted several vent consumers, including the brachyuran crab Bythograea thermidron, the galatheid crab Munidopsis subsquamosa, the zoarcid fish Thermarces cerberus, and the whelk Phymorhynchus starmeri Okutani \& Ohta. Bythograea thermidron was by far the most abundant feeder at the array (Fig. 7). $B$. thermidron visited different food types with significantly different frequencies (first trial: $\chi^{2}=269.3$, df $=6, P<0.001$; second trial: $\chi^{2}=2443.0, \mathrm{df}=6, P$ $<0.001)$. In both trials, mussels and clams ranked first, Riftia second, and limpets last. Crabs fed with similar frequencies on vent mussels and on non-vent clams, suggesting that the high sulfur concentrations in the tissues of vent mussels do not deter crab foraging. Empty Riftia tubes were never visited by crabs during the first trial, and were visited 3.5 times less frequently than whole Riftia individuals during the second trial (Fig. 7), suggesting that crabs were attracted to Riftia as food and not biogenic structure. There was no conclusive evidence that tubes interfere with crabs' foraging; in the second trial crabs tended to Riftia without tubes more frequently than Riftia with intact tubes, but the opposite trend was evident in the first trial (Fig. 7). In both trials, limpets were visited with the lowest frequencies regardless of the substrate they were on; the number of observations of crabs in contact with limpets was similar between limpets associated or not associated with Riftia tubes (Fig. 7).

\section{Stomach-content analyses}

Six Thermarces cerberus fishes (13.3-34.3 cm in standard length) collected from the vestimentiferan zone had prey items that could be identified by microscopic analysis, including benthic amphipods (Ventiella sulfuris Barnard \& Ingram), snails (Cyathermia naticoides), and limpets (Lepetodrilus elevatus and $L$. pustulosus). Each stomach contained the recognizable remains of 3-14 individuals of at least one of these prey species. In addition, 3 of the 6 stomachs contained parts that were recognizable as limpet and amphipod fragments but could not be identified to the species level. Snails were only found in one stomach, which contained 10 individuals. Two additional $T$. cerberus (33.1 and $34 \mathrm{~cm}$ standard length) collected in the bivalve zone of East Wall had unidentifiable material in their stomachs. Similarly, materials contained in the stomachs of 4 brachyuran and 7 galatheid crabs captured in the study area could not be visually identified. None of the crab stomachs contained either gastropods or amphipods.

\section{DISCUSSION}

Our results indicate that environmental conditions around vents underlie most of the variation in the invertebrate communities that developed on recruitment surfaces. Abundances and species richness decline dramatically away from sites of active venting. However, experimental exclusion of predators from recruitment surfaces demonstrated that biotic interactions (predator-prey interactions and probably also biotic disturbance by small mobile grazers on larvae and juveniles) and abiotic factors act jointly to shape developing benthic communities at vents. In the vestimentiferan zone, 
TABle 6. Mean-square terms, $F$ ratios, and significance levels in ANOVAs comparing abundances of the species that explained most variation among blocks, based on PCA results (see Table 4).

\begin{tabular}{|c|c|c|c|c|c|c|c|c|c|c|c|c|c|}
\hline \multirow[b]{2}{*}{ Source } & \multirow[b]{2}{*}{ df } & \multicolumn{2}{|l|}{$\mathrm{Cn}$} & \multicolumn{2}{|c|}{ Le } & \multicolumn{2}{|c|}{$\mathrm{V}$} & \multicolumn{2}{|c|}{ A } & \multicolumn{2}{|c|}{$\mathrm{Lp}$} & \multicolumn{2}{|c|}{$\mathrm{Ag}$} \\
\hline & & $\operatorname{MS\dagger }$ & $F$ & MS $\dagger$ & $F$ & MS $\dagger$ & $F$ & $\operatorname{MS\dagger }$ & $F$ & MS† & $F$ & MS $†$ & $F$ \\
\hline Zone & 3 & 460 & 2.7 & 1053.3 & $99.3 * *$ & 143.2 & $6.1^{*}$ & 166.3 & $14.5 * *$ & 107.5 & $96.2 * *$ & 111.7 & $20.4 * *$ \\
\hline Treatment & 2 & 108 & 0.7 & 56.7 & 2.6 & 28.2 & 1.3 & 57.6 & 3.2 & 1.6 & 0.3 & 8.0 & 2.4 \\
\hline Interaction & 6 & 82.4 & 0.5 & 70.6 & $3.2 *$ & 31.0 & 1.4 & 32.1 & 1.8 & 2.9 & 0.6 & 4.0 & 1.2 \\
\hline $\begin{array}{l}\text { Block group } \\
\text { (zone) }\end{array}$ & 8 & 172.5 & 1.1 & 10.6 & 0.5 & 23.5 & 1.0 & 11.4 & 0.6 & 1.1 & 0.2 & 5.5 & 1.7 \\
\hline Residual & 15 & 161.3 & & 22.2 & & 22.4 & & 17.9 & & 4.4 & & 3.2 & \\
\hline $\begin{array}{l}\text { Total sum of } \\
\text { squares }\end{array}$ & 34 & 6822 & & 4415.1 & & 1129.8 & & 1171.9 & & 414.6 & & 499.3 & \\
\hline
\end{tabular}

Notes: ANOVAs compared abundances among different zones (vestimentiferan, bivalve, suspension-feeder, and periphery zone) and treatments (uncaged blocks, cages, and cage controls) in the 8-mo experiment conducted at East Wall. Abbreviations are: $\mathrm{Cn}=$ Cyathermia naticoides; $\mathrm{Le}=$ Lepetodrilus elevatus; $\mathrm{V}=$ vestimentiferan tubeworms; $\mathrm{A}=$ amphipods; $\mathrm{Lp}=$ Lepetodrilus pustulosus; $\mathrm{Ag}=$ Amphisamytha galapagensis.

$* P<0.05 ; * * P<0.01$.

$\dagger$ Except in last row, where total sums of squares are reported.
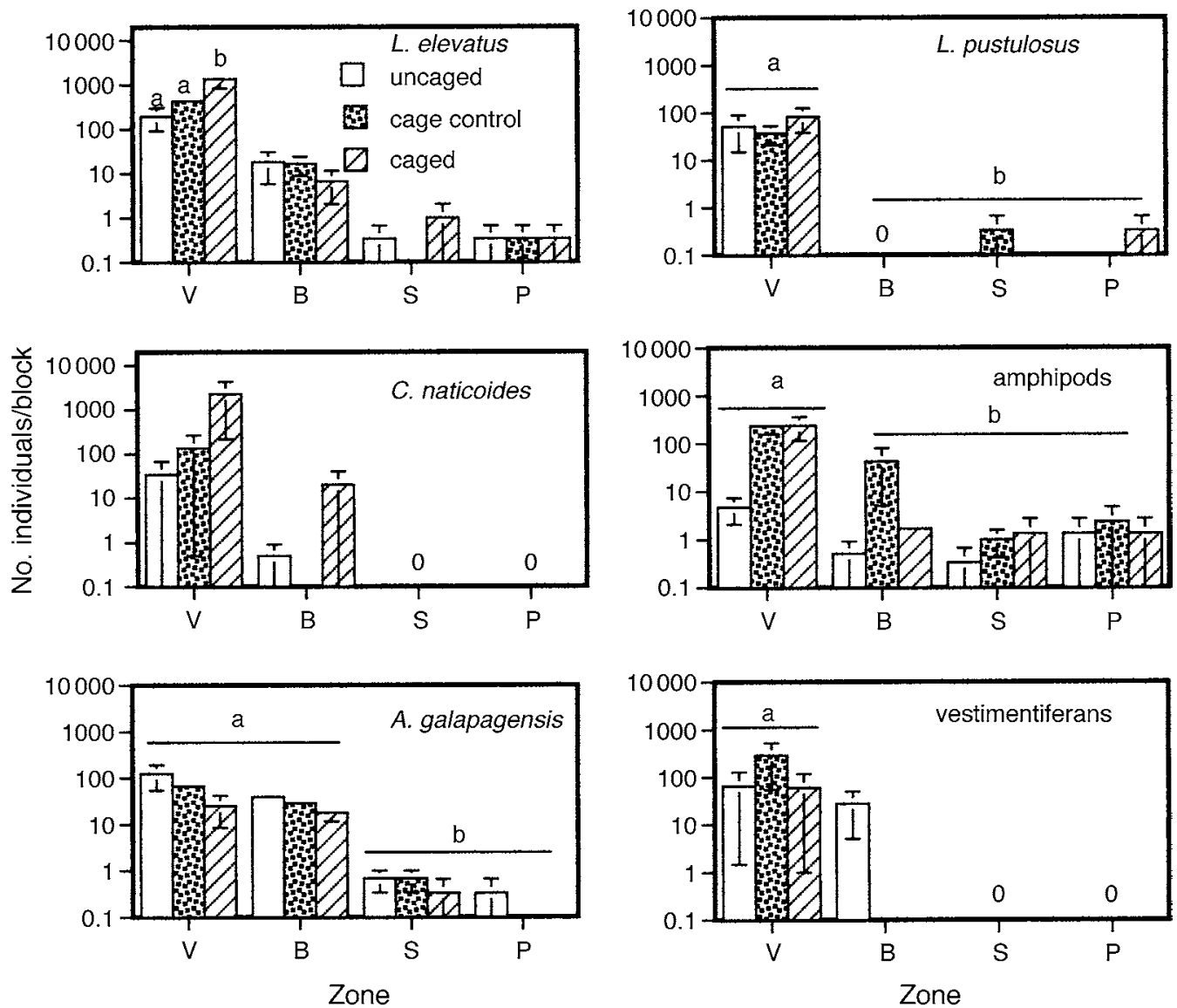

FIG. 4. Patterns of abundance of the species that explained most of the variation among recruitment blocks (see Table 5 for PCA results) in the 8-mo experiment conducted at East Wall with three experimental treatments (uncaged, caged, and cage controls) within each of four zones: vestimentiferan (V), bivalve (B), suspension-feeder (S), and periphery (P) zones $(n=2-3$ blocks each). Bars are means \pm 1 SE. Bars marked with different letters were significantly different at $\alpha=0.05$ (Tukey's test). Caging treatment had a significant effect only on the abundance of Lepetodrilus elevatus in the vestimentiferan zone. Note $\log$ scales on $y$-axes. 
TABLE 7. ANOVAs comparing total number of individuals and species richness among different zones (vestimentiferan, bivalve, suspension-feeder, and periphery zone) and treatments (uncaged and caged blocks) in the 5-mo experiments conducted at three sites (East Wall, Biovent, and Worm Hole).

\begin{tabular}{|c|c|c|c|c|c|c|c|}
\hline \multirow[b]{2}{*}{ Source } & \multirow[b]{2}{*}{$\mathrm{df}$} & \multicolumn{3}{|c|}{ Abundance } & \multicolumn{3}{|c|}{ Number of species } \\
\hline & & MS $\dagger$ & $F$ & $P$ & $\operatorname{MS} \dagger$ & $F$ & $P$ \\
\hline \multicolumn{8}{|l|}{ East Wall } \\
\hline Zone & 3 & 1469.0 & 9.1 & 0.006 & 80.3 & 6.3 & 0.02 \\
\hline Treatment & 1 & 440.2 & 3.6 & 0.10 & 13.3 & 0.6 & 0.46 \\
\hline Interaction & 3 & 275.0 & 2.3 & 0.17 & 16.6 & 0.7 & 0.55 \\
\hline Block group (zone) & 8 & 161.7 & 1.3 & 0.36 & 12.8 & 0.6 & 0.77 \\
\hline Residual & 7 & 121.4 & & & 22.1 & & \\
\hline Total sum of squares & 22 & 8257.4 & & & 579.3 & & \\
\hline \multicolumn{8}{|l|}{ Biovent } \\
\hline Zone & 3 & 567.4 & 36.5 & 0.0001 & 75.3 & 7.7 & 0.01 \\
\hline Treatment & 1 & 172.2 & 7.3 & 0.03 & 0.0 & 0 & 1.00 \\
\hline Interaction & 3 & 75.3 & 3.2 & 0.08 & 6.7 & 0.8 & 0.51 \\
\hline Block group (zone) & 8 & 15.5 & 0.7 & 0.71 & 9.8 & 1.2 & 0.39 \\
\hline Residual & 8 & 23.5 & & & 8.0 & & \\
\hline Total sum of squares & 23 & 2412.7 & & & 388.5 & & \\
\hline \multicolumn{8}{|l|}{ Worm Hole } \\
\hline Zone & 2 & 1701.8 & 7.9 & 0.02 & 130.9 & 14.9 & 0.005 \\
\hline Treatment & 1 & 752.3 & 18.8 & 0.005 & 60.5 & 6.9 & 0.04 \\
\hline Interaction & 2 & 201.4 & 5.0 & 0.05 & 0.7 & 0.1 & 0.93 \\
\hline Block group (zone) & 6 & 215.0 & 5.4 & 0.03 & 8.8 & 1.0 & 0.50 \\
\hline Residual & 6 & 40.0 & & & 8.8 & & \\
\hline Total sum of squares & 17 & 6088.8 & & & 428.9 & & \\
\hline
\end{tabular}

$\dagger$ Except in last row in each panel, where total sums of squares are reported.

TABLE 8. MANOVA and ANOVAs comparing the abundance of mobile $(\mathrm{m})$ and sessile $(\mathrm{s})$ species among different zones (vestimentiferan, bivalve, suspension-feeder, and periphery zone) and treatments (uncaged and caged blocks) in the 5-mo experiments conducted at three sites (East Wall, Biovent and Worm Hole).

\begin{tabular}{|c|c|c|c|c|c|c|c|c|c|c|}
\hline \multirow[b]{4}{*}{ Source } & \multirow[b]{4}{*}{ df } & \multirow{2}{*}{\multicolumn{6}{|c|}{ Univariate ANOVAs }} & \multirow{2}{*}{\multicolumn{3}{|c|}{$\frac{\text { MANOVA }}{(\mathrm{m}, \mathrm{s})}$}} \\
\hline & & & & & & & & & & \\
\hline & & \multicolumn{3}{|c|}{ Mobile species (m) } & \multicolumn{3}{|c|}{ Sessile species (s) } & \multirow{2}{*}{$\begin{array}{l}\text { Wilks' } \\
\text { lambda }\end{array}$} & \multirow[b]{2}{*}{$F$} & \multirow[b]{2}{*}{$P$} \\
\hline & & MS $\dagger$ & $F$ & $P$ & MS $\dagger$ & $F$ & $P$ & & & \\
\hline \multicolumn{11}{|l|}{ East Wall } \\
\hline Zone & 3 & 1306.6 & 8.0 & 0.008 & 97.0 & 1.3 & 0.34 & 0.21 & 2.8 & 0.05 \\
\hline Treatment & 1 & 505.3 & 4.4 & 0.07 & 6.7 & 0.4 & 0.56 & 0.57 & 2.2 & 0.19 \\
\hline Interaction & 3 & 277.9 & 2.4 & 0.15 & 10.3 & 0.6 & 0.65 & 0.44 & 1.0 & 0.46 \\
\hline Block group (zone) & 8 & 162.2 & 1.4 & 0.33 & 75.5 & 4.2 & 0.04 & 0.04 & 3.0 & 0.03 \\
\hline Residual & 7 & 114.1 & 1.4 & & 17.9 & & & & & \\
\hline Total sum of squares & 22 & 7756.3 & & & 1107.6 & & & & & \\
\hline \multicolumn{11}{|l|}{ Biovent } \\
\hline Zone & 3 & 542.7 & 38.8 & 0.0001 & 19.1 & 5.3 & 0.03 & 0.06 & 6.9 & 0.001 \\
\hline Treatment & 1 & 187.5 & $\begin{array}{r}50.0 \\
8.4\end{array}$ & 0.02 & 1.6 & 1.4 & 0.26 & 0.26 & 9.7 & 0.01 \\
\hline Interaction & 3 & 88.9 & 4.0 & 0.05 & 5.2 & 4.7 & 0.04 & 0.10 & 5.0 & 0.01 \\
\hline Block group (zone) & 8 & 14.0 & 0.6 & 0.74 & 3.6 & 3.2 & 0.06 & 0.12 & 1.6 & 0.18 \\
\hline Residual & 8 & 22.3 & & 0.74 & 1.1 & & & & & \\
\hline Total sum of squares & 23 & 2372.8 & & & 112.4 & & & & & \\
\hline \multicolumn{11}{|l|}{ Worm Hole } \\
\hline Zone & 2 & 1725.7 & 7.6 & 0.02 & 64.7 & 7.4 & 0.02 & 0.12 & 4.6 & 0.02 \\
\hline Treatment & 1 & 1035.0 & 29.7 & 0.002 & 26.7 & 2.2 & 0.19 & 0.15 & 14.4 & 0.008 \\
\hline Interaction & 2 & 205.3 & 5.9 & 0.04 & 6.8 & 0.6 & 0.60 & 0.28 & 2.2 & 0.14 \\
\hline Block group (zone) & 6 & 228.1 & 6.5 & 0.02 & 8.7 & 0.7 & 0.66 & 0.08 & 2.1 & 0.12 \\
\hline Residual & 6 & 34.8 & & & 12.4 & & & & & \\
\hline Total sum of squares & 17 & 6474.7 & & & 296.1 & & & & & \\
\hline
\end{tabular}

$\dagger$ Except in last row in each panel, where total sums of squares are reported. 
Total abundance
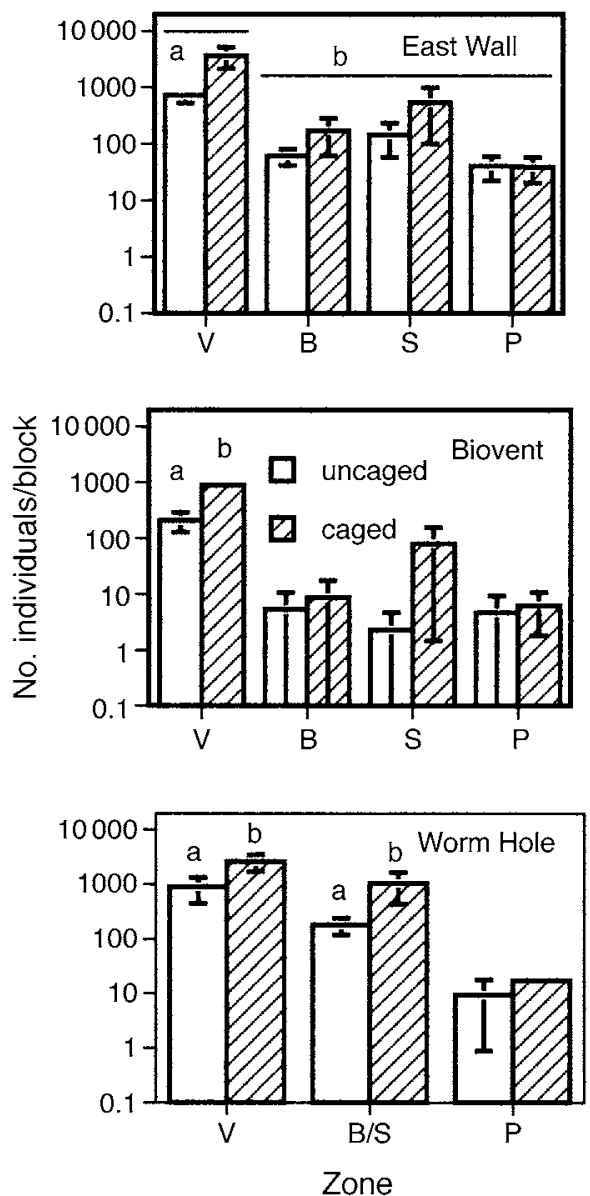

Taxon richness
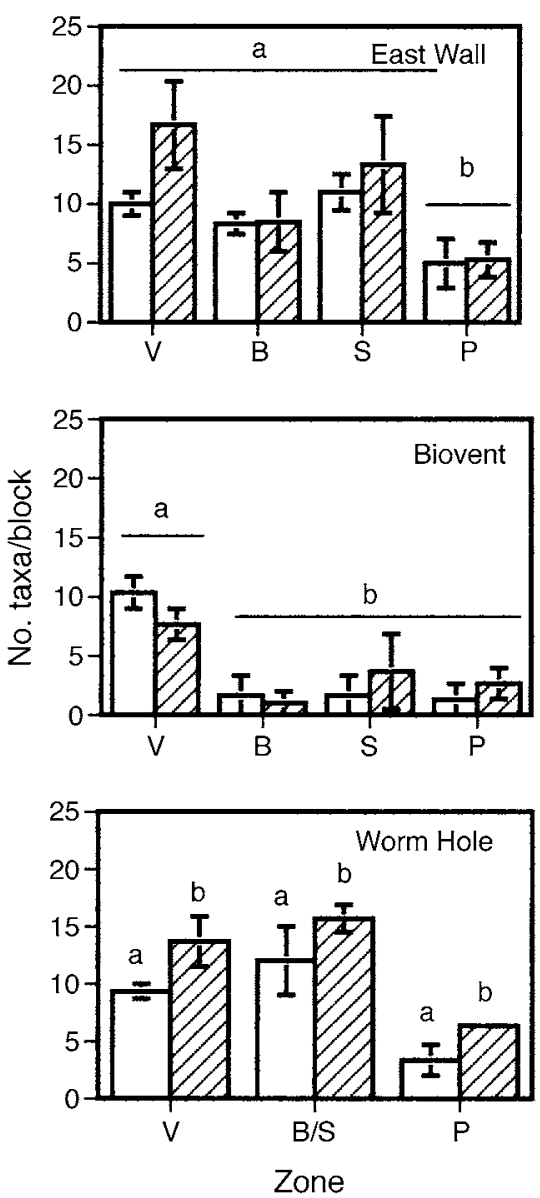

FIG. 5. Patterns of total abundance and species richness of the invertebrate community that developed on recruitment blocks during 5-mo experiments conducted at three sites (East Wall, Biovent, and Worm Hole) with two experimental treatments (uncaged and caged blocks) within each of four zones: vestimentiferan (V), bivalve (B), suspension-feeder (S), and periphery (P) zone $(n=3$ blocks each). The bivalve and the suspension-feeder zones were combined at Worm Hole. Bars are means \pm 1 SE. Bars marked with different letters were significantly different at $\alpha=0.05$ (Tukey's test). Note log scales on $y$-axes in the three left-hand panels.

where abiotic conditions are most extreme but prey and predators, as well as microbial food supplies, are most abundant, predator exclusion caused the abundance of gastropods to increase by up to an order of magnitude. In the other zones, abundances were lower and predation effects were less obvious. Similar to the results of the 8-mo experiment, trends of declining total abundances with diminishing exposure to venting fluids and greater abundances of small mobile grazers within cages than on uncaged blocks in the vestimentiferan zone were already apparent in the 5-mo experiments and were observed at three different locations. The fact that dramatic community responses to predator exclusion occurred over such short time scales (e.g., months) confirms previous observations that vent communities are highly dynamic (Hessler et al. 1988, Haymon et al. 1991, Lutz et al. 1994). Moreover, predation effects are general: they occurred early in the colonization se- quence, tended to persist through time, and were observed at different locations.

Biotic interactions appear most important in shaping hydrothermal vent communities where physical conditions are most extreme and variable but where productivity is the highest. The physical processes that cause temperatures, $\mathrm{pH}$, oxygen, sulfide, and metals concentrations to reach extreme values also support biological productivity at vents. In most ecological systems exhibiting steep gradients in abiotic conditions, such as the intertidal zonation on rocky shores and the altitudinal gradients of mountainsides, extreme and variable environmental conditions tend to coincide with the least productive end of the environmental gradient. Environmental gradients around hydrothermal vents are fundamentally different from those of other ecosystems in that the most extreme and variable conditions correspond to the most productive end of the 
Mobile species
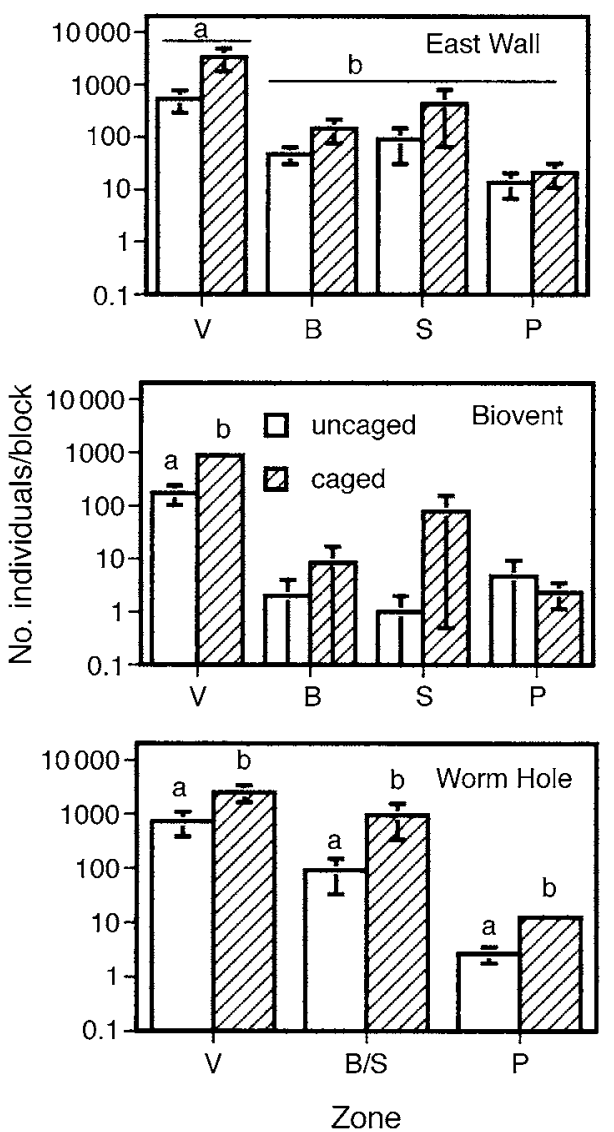

Sessile species
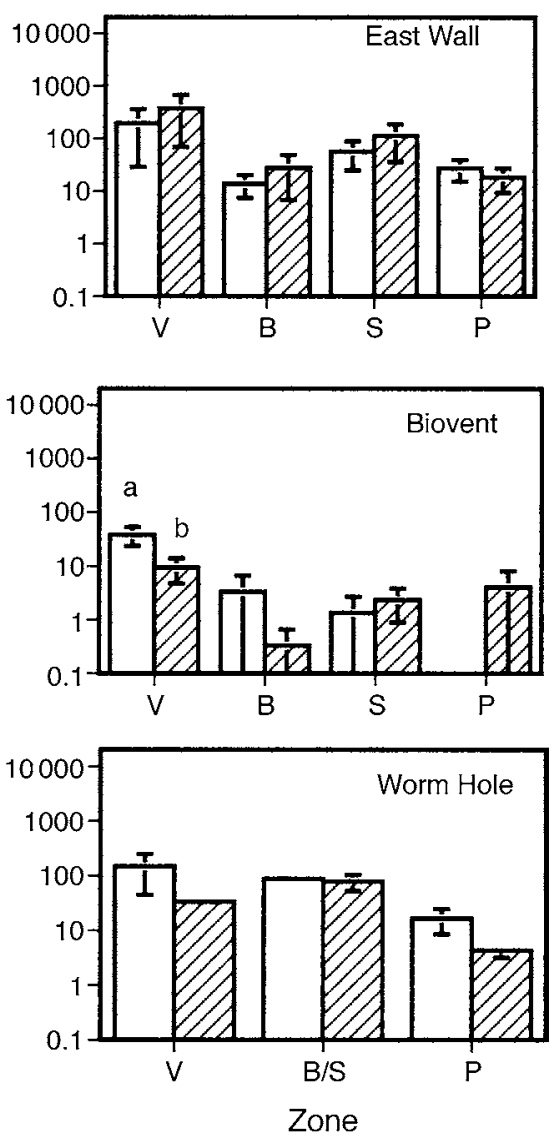

FIG. 6. Patterns of abundance of mobile and sessile species on recruitment blocks during the 5-mo experiment conducted at three sites (East Wall, Biovent, and Worm Hole) with two experimental treatments (uncaged and caged blocks) within each of four zones: vestimentiferan (V), bivalve (B), suspension-feeder (S), and periphery (P) zone ( $n=3$ blocks each). The bivalve and the suspension-feeder zones were combined at Worm Hole. Bars are means \pm 1 SE. Bars marked with different letters were significantly different at $\alpha=0.05$ (Tukey's test). Note log scales on $y$-axes.

gradient (C. H. Peterson et al., unpublished manuscript). When resources are most rapidly produced in extreme environments, there should be selection among consumers for physiological tolerances needed to exploit those environments. Such physiological adaptations allow rapid accumulation and transfer of biomass across trophic levels, leading to cascading effects of trophic interactions (e.g., Fretwell 1977, Oksanen et al. 1981).

Variability among block groups within each zone was high for all experiments, though often not statistically significant. Temperatures measured during deployment and recovery of blocks indicated that venting activity, and thus the suite of associated physical and chemical characteristics of the water (Johnson et al. 1988a, b, 1994, Von Damm et al. 1995), was highly variable even within zones (Table 1). Our results show that there are clear differences among zones in community composition, both in species and functional group abundances, and in the outcome of biological interactions. However, replication in space and time was insufficient to investigate how physical variability occurring at smaller scales, among microhabitats found within each zone, influences community development. More extensive experimental manipulations and physical measurements are needed to elucidate the relationship between small-scale variation of environmental conditions and community development at vents.

Our caging experiments and stomach-content analyses suggest that large epibenthic predators (mostly zoarcid fish) influence benthic community structure at hydrothermal vents by keeping small mobile grazers in check, thereby decreasing mortality of sessile invertebrates and allowing their establishment on colonization surfaces. Trophic interactions cascading through the food web to influence vent benthic communities begin as interactions among a small subset of the species present. In particular, the zoarcid fish Thermarces cerberus influences benthic populations directly by preying upon the gastropods Lepetodrilus elevatus and Cyathermia naticoides (Geistdoerfer 1986, 1996; this study) and controlling their abundance, and 


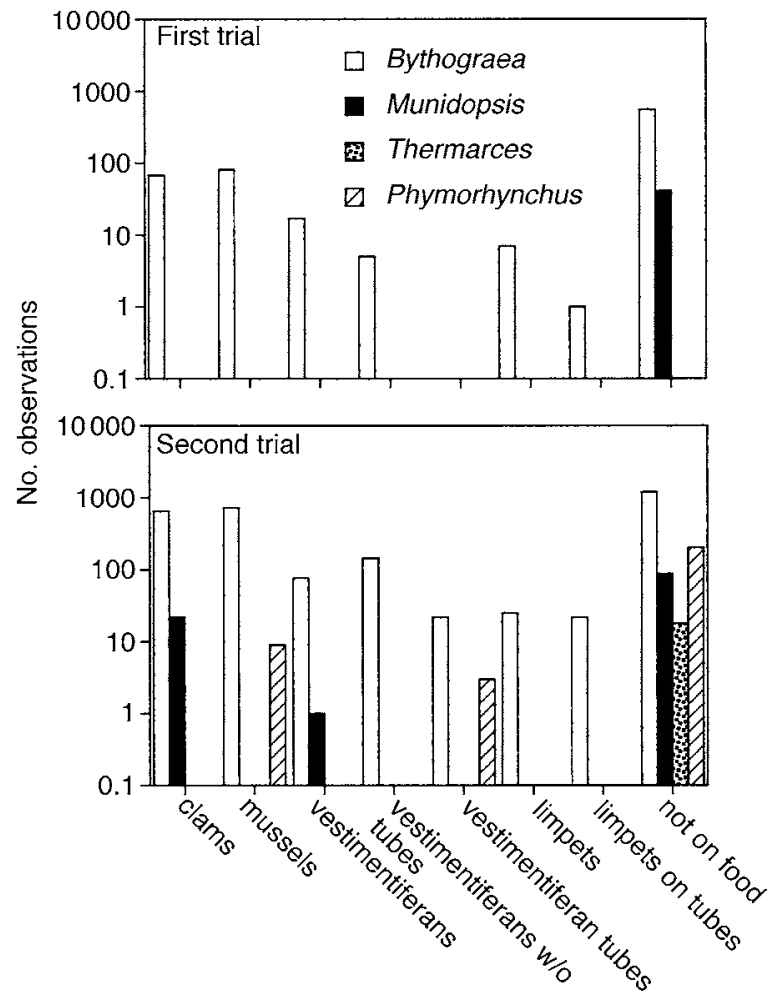

Food type

FIG. 7. Results of the feeding-choice experiments conducted in the vestimentiferan zone of East Wall. Bars represent the log-transformed number of observations of each consumer species feeding on one of seven food items presented in the course of two separate trials. The number of observations of consumers not in direct contact with any of the food items ("not on food") is also reported. Clams, Megapitaria squalida; mussels, Bathymodiolus thermophilus; vestimentiferans, Riftia pachyptila; vestimentiferans w/o tube, Riftia with tube removed; vestimentiferan tubes, Riftia tubes; limpets, Lepetodrilus elevatus; limpets on tubes, $L$. elevatus on Riftia tubes. Note log scales on $y$-axes. indirectly through interactions between these prey species and other species in the community. Small mobile grazers, including limpets, snails, and amphipods, may interfere with the recruitment success of sessile invertebrates through different mechanisms. Mobile grazers may directly consume newly settled larvae and juveniles or may increase their postsettlement mortality by bulldozing, disturbing, and killing postlarvae and juveniles (Dayton 1971). Grazers may also decrease recruitment rates indirectly, by modifying the characteristics of the substrate. In particular, grazers may remove the bacterial film covering the rock, which may serve as a settlement cue for larvae (Keough and Raimondi 1995).

The effects of caging treatment on mobile invertebrates are unlikely to be caused by artifacts of the cages. Abundances were similar between full cages and cage controls only for one taxon, the amphipods (Fig. 4). Amphipod abundances may have been enhanced by the cage structure and not through predator exclusion. Because of the potential caging artifact influencing the response of amphipods to the predator-exclusion treatment, we re-analyzed the results of the 8-mo experiment after excluding this taxon from the data set. Results show that the effect of the caging treatment on mobile species was still statistically significant when amphipods were excluded (Table 9). In fact, the effects of caging were more clear-cut in that abundances were significantly greater within cages than either on uncaged blocks or cage controls, with no difference between these two treatments. The most common mobile invertebrate found on blocks, the limpet Lepetodrilus elevatus, had also significantly greater abundance in cages than either uncaged blocks or cage controls in the vestimentiferan zone (Table 6 and Fig. 4). Thus, abundances of small mobile invertebrates, particularly limpets, were at least partly influenced by predator exclusion. However, caging artifacts may have contributed to enhancing abundances of mobile invertebrates inside cages in at least three ways: (1) by providing

TABlE 9. MANOVA and ANOVAs comparing the abundance of mobile (m) and sessile (s) species among zones (vestimentiferan, bivalve, suspension-feeder, and periphery zone) and treatments (uncaged blocks, cages, and cage controls) in the 8-mo experiment conducted at East Wall.

\begin{tabular}{|c|c|c|c|c|c|c|c|c|c|c|}
\hline \multirow[b]{4}{*}{ Source } & \multirow[b]{4}{*}{ df } & \multirow{2}{*}{\multicolumn{6}{|c|}{ Univariate ANOVAs }} & \multirow{2}{*}{\multicolumn{3}{|c|}{$\begin{array}{c}\text { MANOVA } \\
(\mathrm{m}, \mathrm{s}) \\
\end{array}$}} \\
\hline & & & & & & & & & & \\
\hline & & \multicolumn{3}{|c|}{ Mobile species (m) } & \multicolumn{3}{|c|}{ Sessile species (s) } & \multirow{2}{*}{$\begin{array}{l}\text { Wilks' } \\
\text { lambda }\end{array}$} & \multirow[b]{2}{*}{$F$} & \multirow[b]{2}{*}{$P$} \\
\hline & & MS $\dagger$ & $F$ & $P$ & MS† & $F$ & $P$ & & & \\
\hline Zone & 3 & 2218.8 & 31.1 & 0.0001 & 284.6 & 19.1 & 0.0005 & 0.04 & 8.9 & 0.0004 \\
\hline Treatment & 2 & 240.5 & $\begin{array}{r}5.1 \\
5.4\end{array}$ & 0.02 & 14.5 & 1.1 & 0.35 & 0.46 & 3.3 & 0.03 \\
\hline Interaction & 6 & 184.1 & 4.1 & 0.01 & 2.1 & 0.2 & 0.98 & 0.33 & 1.7 & 0.12 \\
\hline Block group (zone) & 8 & 71.5 & 1.6 & 0.21 & 14.9 & 1.2 & 0.38 & 0.37 & 1.1 & 0.37 \\
\hline Residual & 15 & 44.7 & & & 12.9 & & & & & \\
\hline Total sum of squares & 34 & 10536.8 & & & 11257.3 & & & & & \\
\hline
\end{tabular}

Notes: Amphipods were excluded from the analyses because their high abundances in the cage controls suggested that they had responded to the cage structure and not to predator exclusion. Wilks' lambda was used to test significance in MANOVA.

$\dagger$ Except in last row, where total sums of squares are reported. 
additional recruitment surface on cage walls (for example, we did observe some limpets and polychaetes on the plastic mesh); (2) by baffling flows and increasing deposition rates of particles, including larvae (it is suggested by our observation that flocculent material tended to accumulate inside the full cages and the cage controls); and (3) by retaining more individuals during block recovery, thereby reducing losses due to the detachment of organisms from the blocks when these were picked up by the submersible manipulators. Cages may also have influenced invertebrate abundances through the mechanisms listed above, in addition to the exclusion of predators.

Predation influences the structure of vent benthic communities through chains of species interactions similar to those described in a variety of aquatic ecosystems, including rocky shores (Paine 1966, Wootton 1992, 1993, Lindberg et al. 1998), kelp beds (Estes and Palmisano 1974, Estes et al. 1998), lakes (Carpenter and Kitchell 1993), and streams (Power 1990, Wootton and Power 1993). For example, birds prey on limpets and control their abundances on some rocky shores, which in turn can have direct and indirect effects on macroalgae and sessile invertebrates (Hockey and Branch 1984, Wootton 1992, 1993, Lindberg et al. 1998). The mechanisms through which predators affect whole communities vary greatly among different types of communities, among locations and through time (Hixon 1986). Nevertheless, in hydrothermal vent communities and in other ecosystems, the impact of predation on prey community structure appears to be most pronounced when predators selectively remove prey that are strong interactors in the system because of competitive or predator-prey interactions with other species (e.g., Paine 1966).

The abundant brachyuran and galatheid crabs found at hydrothermal vents of the EPR are unlikely to have caused the caging effects in the predator-exclusion experiments. In feeding-preference experiments, brachyuran crabs preferred Riftia and mussels to limpets. These results may be biased by our use of dead organisms in the food-choice experiments. However, results of these experiments are corroborated by the finding that none of the stomachs of the crabs collected in the study area contained identifiable limpet, snail, or amphipod remains. Moreover, stable isotope-ratio analyses and direct observations of crab foraging (Fisher et al. 1994; L. Mullineaux, C. Fisher, and F. Micheli, personal observations) confirm that crabs actively feed on the vestimentiferan worm Riftia and the mussel Bathymodiolus through scavenging on dead individuals, "nipping" of the plumes and siphons of live animals, and possibly through killing and consuming the whole animals. We used the results of field experiments, behavioral observations, and stomach-content analyses to construct a preliminary food web depicting interactions and impacts among the most abundant vent species (Fig. 8). Whereas the influence of fishes on

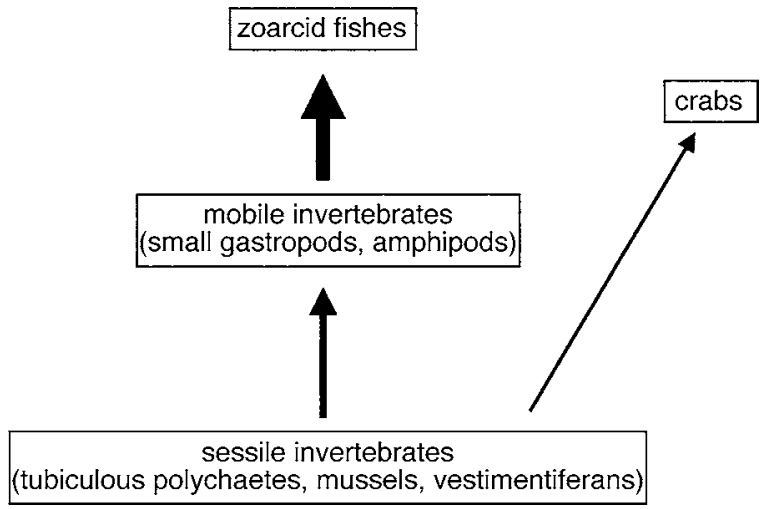

FIG. 8. Food web describing interactions among the most abundant deep-sea hydrothermal vent species in the study area $\left(9^{\circ} 50^{\prime} \mathrm{N}\right.$ on the East Pacific Rise). Arrow thickness reflects the hypothesized relative interaction strength. Zoarcid fish had strong and significant effects on small gastropods in the predator-exclusion experiments. Sessile invertebrates varied among caged and uncaged blocks consistent with the hypothesis that small grazers may influence their recruitment, but trends were not statistically significant (hence the thinner arrow). Crabs commonly feed on vestimentiferans and mussels, but their effects on these species are unknown.

benthic invertebrates was well supported by our results, the presumptive effects of crabs on the population and community dynamics of sessile invertebrates were not evident in our experimental results. Brachyuran crabs may influence vestimentiferan and mussel populations in well-established vent communities, through partial predation on adult individuals. On the other hand, they may simply graze and not kill this prey, having a limited effect at the level of populations. Our experiments investigated species interactions occurring during the early development of vent communities. Longer term experiments are needed to clarify the structure and variability of interaction webs within hydrothermal vent communities.

Deep-sea hydrothermal vents are highly variable environments, and the factors and processes that structure these communities are likely to vary in time and space and depending on the history of each particular location. Nevertheless, these experimental manipulations show that abiotic gradients and biotic interactions act jointly to shape vent benthic communities, producing community patterns that are repeatable between the different time intervals and locations of our experiments. In particular, we provide direct evidence that biotic interactions play a substantial role in the early development of deep-sea hydrothermal vent communities (see also Mullineaux et al. 2000), and show that the conceptual models and methodologies developed for other ecosystems can be utilized to unravel the ecological processes shaping these unique communities.

\section{ACKNOWLEDGMENTS}

We thank the pilots and crew of the ALVIN group and the crew of the RV Atlantis for their help and support, E. Agen- 
broad, S. Kim, M. Nakaoka, B. Ripley, and S. Schaeffer for their help with laboratory and field work, and E. Seabloom and L. Benedetti-Cecchi for statistical advice. We also thank M. Hixon, R. Paine, and an anonymous reviewer for useful suggestions on the manuscript. D. Fornari supplied, prepared, and maintained the camera system used in the feeding-preference experiments. This work was funded by National Science Foundation grants OCE-9315554 and OCE-9712233 to L. S. Mullineaux, OCE-9317735 and OCE-9712809 to C. H. Peterson, and OCE-9317737 and OCE 9712808 to C. R. Fisher. Parts of this study were conducted while F. Micheli was a postdoctoral researcher at the National Center for Ecological Analysis and Synthesis, a center funded by NSF, the University of California, Santa Barbara, and the California Resource Agency.

\section{Literature Cited}

Bertness, M. D., and R. Callaway. 1994. Positive interactions in communities. Trends in Ecology and Evolution 9:191193.

Bertness, M. D., G. H. Leonard, J. M. Levine, P. R. Schmidt, and A. O. Ingraham. 1999. Testing the relative contribution of positive and negative interactions in rocky intertidal communities. Ecology 80:2711-2726.

Bustamante, R. H., G. M. Branch, S. Eekhout, B. Robertson, P. Zoutendyk, M. Schleyer, A. Dye, N. Hanekom, D. Keats, M. Jurd, and C. McQuaid. 1995. Gradients of intertidal primary productivity around the coast of South Africa and their relationships with consumer biomass. Oecologia 102: 189-201.

Carpenter, S. R., and J. F. Kitchell, editors. 1993. The trophic cascade in lakes. Cambridge University Press, Cambridge, UK.

Childress, J. J., and C. R. Fisher. 1992. The biology of hydrothermal vent animals: physiology, biochemistry and autotrophic symbioses. Oceanography and Marine Biology Annual Reviews 30:337-441.

Connell, J. H. 1961. Effects of competition, predation by Thais lapillus, and the other factors on natural populations of the barnacle Balanus balanoides. Ecological Monographs 31:61-104.

Connell, J. H. 1972. Community interactions on marine rocky intertidal shores. Annual Review of Ecology and Systematics 3:169-191.

Dayton, P. K. 1971. Competition, disturbance and community organization: the provision and subsequent utilization of space in a rocky intertidal community. Ecological Monographs 41:351-389.

Desbruyères, D., and M. Segonzac. 1997. Handbook of deepsea hydrothermal vent fauna. Editions IFREMER, Brest, France.

Detrick, R. S., P. Buhl, E. Vera, J. Orcutt, J. Madsen, and T. Brocher. 1987. Multi-channel seismic imaging of a crustal magma chamber along the East Pacific Rise. Nature 326: 35-41.

Estes, J. A., and J. F. Palmisano. 1974. Sea otters: their role in structuring nearshore communities. Science 185:10581060 .

Estes, J. A., M. T. Tinker, T. M. Williams, and D. F. Doak. 1998. Killer whale predation on sea otters linking oceanic and nearshore ecosystems. Science 282:473-476.

Fisher, C. R., J. J. Childress, S. A. Macko, and J. M. Brooks. 1994. Nutritional interactions in Galapagos Rift hydrothermal vent communities: inferences from stable carbon and nitrogen isotope analyses. Marine Ecology Progress Series 103:45-55.

Fretwell, S. D. 1977. The regulation of plant communities by food chains exploiting them. Perspectives in Biology and Medicine 20:169-185.

Gaines, S. D., and J. Roughgarden. 1985. Larval settlement rate: a leading determinant of community structure in an ecological community of the marine intertidal zone. Proceedings of the National Academy of Sciences (USA) 82: 3707-3711.

Geistdoerfer, P. 1986. Nouvelles captures et redescription d'un poisson Zoarcidae (Pisces, Perciformes, Zoarcoidei) des sites hydrothermaux de la ride du Pacifique oriental. Bulletin du Musée National d'Histoire Naturelle de Paris 4e serie 8:969-980.

Geistdoerfer, P. 1996. L'ichthyofaune des ecosystemes associés à 1'hydrothermalisme oceanique: etat des connaissances et résultats nouveaux. Oceanologica Acta 19:539_ 548 .

Grassle, J. F. 1986. The ecology of deep-sea hydrothermal vent communities. Advances in Marine Biology 23:301362.

Haymon, R. M., D. J. Fornari, M. H. Edwards, S. Carbotte, D. Wright, and K. C. Macdonald. 1991. Hydrothermal vent distribution along the East Pacific Rise crest $\left(9^{\circ} 9^{\prime}-54^{\prime} \mathrm{N}\right)$ and its relationship to magmatic and tectonic processes on fast-spreading mid-ocean ridges. Earth and Planetary Science Letters 104:513-534.

Hessler, R. R., W. M. Smithey, M. A. Boudrias, C. H. Keller, R. A. Lutz, and J. J. Childress. 1988. Temporal change in megafauna at the Rose Garden hydrothermal vent (Galapagos Rift; eastern tropical Pacific). Deep Sea Research 35: 1681-1709.

Hixon, M. A. 1986. Fish predation and local prey diversity. Pages 235-257 in C. A. Simenstad and G. M. Cailliet, editors. Contemporary studies on fish feeding. Dr W. Junk, Dordrecht, The Netherlands.

Hockey, P. A. R., and G. M. Branch. 1984. Oystercatchers and limpets: impact and implications. A preliminary assessment. Ardea 72:199-206.

Johnson, K. S., J. J. Childress, and C. L. Beehler. 1988 b. Short-term temperature variability in the Rose Garden hydrothermal vent field: an unstable deep-sea environment. Deep Sea Research 35:1711-1721.

Johnson, K. S., J. J. Childress, C. L. Beehler, and C. M. Sakamoto-Arnold. 1994. Biogeochemistry of hydrothermal vent mussel communities: the deep-sea analogue to the intertidal zone. Deep Sea Research 41:993-1011.

Johnson, K. S., J. J. Childress, R. R. Hessler, C. M. SakamotoArnold, and C. L. Beehler. 1988a. Chemical and biological interactions in the Rose Garden hydrothermal vent field, Galapagos spreading center. Deep Sea Research 35:17231744.

Keough, M. J., and P. T. Raimondi. 1995. Responses of settling invertebrate larvae to bioorganic films: effects of different types of films. Journal of Experimental Marine Biology and Ecology 185:235-253.

Kim, S. L., L. S. Mullineaux, and K. R. Helfrich. 1994. Larval dispersal via entrainment into hydrothermal vent plumes. Journal of Geophysical Research 99:12655-12665.

Lindberg, D. R., J. A. Estes, and K. I. Warheit. 1998. Human influences on trophic cascades along rocky shores. Ecological Applications 8:880-890.

Luther, G. W., III, T. F. Rozan, M. Taillefert, D. B. Nuzzio, C. Di Meo, T. M. Shank, R. A. Lutz, and S. C. Cary. 2001. Chemical speciation drives hydrothermal vent ecology. Nature 410:813-816.

Lutz, R. A., T. M. Shank, D. J. Fornari, R. M. Haymon, M. D. Lilley, K. L. Von Damm, and D. Desbruyères. 1994. Rapid growth at deep-sea vents. Nature 371:663-664.

Menge, B. A. 1976. Organization of the New England rocky intertidal community: role of predation, competition and environmental heterogeneity. Ecological Monographs 46: 355-393.

Menge, B. A. 1995. Indirect effects in marine rocky intertidal interaction webs: patterns and importance. Ecological Monographs 65:21-74. 
Menge, B. A., E. L. Berlow, C. A. Blanchette, S. A. Navarrete, and S. B. Yamada. 1994. The keystone species concept: variation in interaction strength in a rocky intertidal habitat. Ecological Monographs 64:249-286.

Menge, B. A., and T. M. Farrell. 1989. Community structure and interaction webs in shallow marine hard-bottom communities: tests of an environmental stress model. Advances in Ecological Research 19:189-262.

Menge, B. A., and J. P. Sutherland. 1976. Species diversity gradients: synthesis of the roles of predation, competition, and temporal heterogeneity. American Naturalist 110:351369.

Menge, B. A., and J. P. Sutherland. 1987. Community regulation: variation in disturbance, competition, and predation in relation to environmental stress and recruitment. American Naturalist 130:730-757.

Mullineaux, L. S., C. R. Fisher, C. H. Peterson, and S. W. Schaeffer. 2000. Tubeworm succession at hydrothermal vents: use of biogenic cues to reduce habitat selection error? Oecologia 123:275-284.

Mullineaux, L. S., S. W. Mills, and E. Goldman. 1998. Recruitment variation during a pilot colonization study of hydrothermal vents $\left(9^{\circ} 50^{\prime} \mathrm{N}\right.$, East Pacific Rise). Deep Sea Research 45:441-464.

Newell, R. C. 1976. Adaptations to intertidal life. Pages 182 in R. C. Newell, editor. Adaptations to environment: essays on the physiology of marine animals. Butterworth, Sydney, Australia.

Oksanen, L., S. J. Fretwell, J. Arruda, and P. Niemela. 1981. Exploitation ecosystems in gradients of primary productivity. American Naturalist 118:240-261.

Paine, R. T. 1966. Food web complexity and species diversity. American Naturalist 100:65-75.

Peterson, C. H. 1979. The importance of predation and competition in organizing the intertidal epifaunal communities of Barnegat Inlet, New Jersey. Oecologia 39:1-24.

Power, M. E. 1990. Effects of fish in river food webs. Science 250:811-814.

Raffaelli, D., and H. Moller. 1999. Manipulative experiments in animal ecology: do they promise more than they can deliver? Advances in Ecological Research 30:299-338.
Roughgarden, J., S. D. Gaines, and H. Possingham. 1988. Recruitment dynamics in complex life cycles. Science 241: 1460-1466.

Sousa, W. P. 1979. Experimental investigations of disturbance and ecological succession in a rocky intertidal community. Ecological Monographs 49:227-254.

Stephenson, T. A., and A. Stephenson. 1972. Life between tide marks on rocky shores. W. H. Freeman, San Francisco, California, USA

Tunnicliffe, V. 1991. The biology of hydrothermal vents: ecology and evolution. Oceanography and Marine Biology Annual Reviews 29:319-407.

Tunnicliffe, V., and S. K. Juniper. 1990. Dynamic character of the hydrothermal vent habitat and the nature of sulphide chimney fauna. Progress in Oceanography 24:1-13.

Underwood, A. J., and E. J. Denley. 1984. Paradigms, explanations and generalizations in models of the structure of intertidal communities on rocky shores. Pages 151-180 in D. Simberloff et al., editors. Ecological communities: conceptual issues and the evidence. Princeton University Press, Princeton, New Jersey, USA.

Van Dover, C. L. 1995. Ecology of mid-Atlantic ridge hydrothermal vents. Pages 257-294 in L. M. Parsons, C. L. Walker, and D. R. Dixon, editors. Hydrothermal vents and processes. Special Publication 87, Geological Society, London, UK.

Von Damm, K. L., S. E. Oosting, R. Kozwloski, L. G. Buttermore, D. C. Colodner, H. N. Edmonds, J. M. Edmond, and J. M. Grebmeier. 1995. Evolution of east Pacific Rise hydrothermal vent fluids following a volcanic eruption. Nature 375:47-50.

Wootton, J. T. 1992. Indirect effects, prey susceptibility, and habitat selection: impacts of birds on limpets and algae. Ecology 73:981-991.

Wootton, J. T. 1993. Indirect effects and habitat use in an intertidal community: interaction chains and interaction modifications. American Naturalist 141:71-89.

Wootton, J. T., and M. E. Power. 1993. Productivity, consumers, and the structure of a river food chain. Proceedings of the National Academy of Sciences (USA) 90:13841387 . 